WIDER Working Paper 2016/131

\title{
The political economy of 'linked' progressive taxation in Africa and Latin America
}

Paul Mosley ${ }^{1}$ and Abdul-Gafaru Abdulai ${ }^{2}$

November 2016 
Abstract: One key element in the reduction of poverty and (in Latin America) inequality has been the achievement of greater fiscal equity; we analyse one key part of this process, which is the earmarking of portions of tax revenue to be spent on progressive public expenditures such as social protection, health, and education. Such 'linkage' yields a political dividend, and may also help to strengthen the tax base, but at the same time constrains the flexibility with which public revenue can be switched between sectors. We examine, principally by regression methods, the impact of 'linked taxation' in five countries-Bolivia, Ecuador, Venezuela, Zambia, and Ghana - and find that it significantly reduces political instability and raises tax revenue in all those countries. 'Linked progressive taxation' has evolved over recent years to become more flexible, in particular through reforms in the sources and types of taxation which are used to finance priority expenditures, and we argue that these adaptations have helped to reduce the inefficiencies associated with linked taxation.

Keywords: taxation, public expenditure, political economy, redistribution, Africa, Latin America JEL classification: $\mathrm{H} 2, \mathrm{H} 5, \mathrm{O} 2$

${ }^{1}$ University of Sheffield, Sheffield, United Kingdom; ${ }^{2}$ University of Ghana Business School, Legon, Accra, Ghana; corresponding author: p.mosley@sheffield.ac.uk.

This study has been prepared within the UNU-WIDER project on 'The political economy of social protection systems', which is part of a larger research project on 'The economics and politics of taxation and social protection'.

Copyright (C) UNU-WIDER 2016

Information and requests: publications@wider.unu.edu

ISSN 1798-7237 ISBN 978-92-9256-175-8

Typescript prepared by Gary Smith.

The United Nations University World Institute for Development Economics Research provides economic analysis and policy advice with the aim of promoting sustainable and equitable development. The Institute began operations in 1985 in Helsinki, Finland, as the first research and training centre of the United Nations University. Today it is a unique blend of think tank, research institute, and UN agency — providing a range of services from policy advice to governments as well as freely available original research.

The Institute is funded through income from an endowment fund with additional contributions to its work programme from Denmark, Finland, Sweden, and the United Kingdom.

Katajanokanlaituri 6 B, 00160 Helsinki, Finland

The views expressed in this paper are those of the author(s), and do not necessarily reflect the views of the Institute or the United Nations University, nor the programme/project donors. 
In many poorer developing countries, what prevents a breakthrough into sustained development is weakness in the fiscal system, both on the taxation and the expenditure side. Often they are trapped in a circular process in which, not being able to raise taxes or impose new ones for fear of political instability, they are consequently not able to develop public expenditure to the point of being able to deliver a sustained improvement in living standards, meaning their governments continue to be fragile (Brautigam et al. 2008; Moore 1999; Mosley 2015a).

As many countries have shown, escape from this vicious circle is possible. Typically, the escape route has involved a combination of imagination in the design of new taxes and expenditure programmes, the administrative skills required to implement them, and also political-economy skills; the last of these is crucial, as without these skills no escape from the weak-state tax dilemma is possible. It is these skills we focus on in this paper, with particular emphasis on one of the most fascinating escape routes: the approach that we call 'linked progressive taxation', in which the required increase in tax revenue comes from new taxes either on exports by multinational companies (which have historically been undertaxed on account of the power of oil and mining multinationals) or on other predominantly high-income tax bases, which are then made both more redistributive and more politically attractive by being earmarked for spending on social protection, human capital, or various kinds of labour-intensive expenditure.

The idea of linked taxation was conceived in Latin America: as far back as the 1930s, naturalresource exports were heavily taxed to finance industrialization in Argentina, Mexico, and Chile (Bulmer-Thomas 2014; Cardoso and Helwege 1995). At this stage, however, the link was informal: there was no formal earmarking of revenues to specific expenditure functions, nor did tax reform have a redistributive rhetoric attached to it. All this changed in the early 2000s, when, in a number of countries, linked taxation became part of the 'neodevelopmentalist' fiscal programmes which, in response to the crises of that time in Southern Cone economies such as Argentina, Bolivia, and Brazil, sought to reposition their economic strategy on a more autonomous basis, less beholden to the dictates of the Washington Consensus (Grugel and Riggirozzi 2009) and more responsive to the demands of increasingly politicized lower-income groups. Export taxation, and specifically the taxation of natural-resource exports, absolutely antithetical to the principles of the Consensus, was often, although not always, a key element in such strategies. ${ }^{1}$ In a variety of Latin American countries in this decade, however, the idea was also pioneered of earmarking such taxation to be spent on various forms of redistributive expenditure-especially conditional cash transfers linked to attendance by children at schools and health centres, which in various alternative forms were sweeping the continent at the time (e.g. Barrientos and Santibañez 2009); this reinforced the political dividend yielded by the taxation of multinationals. ${ }^{2}$ The idea then, as we shall see, made its way across to Africa, mutating as it went, in the sense that not all linked taxation was attached to natural resources. The common factor in all of these cases, we argue, was that a new linkage between taxation and redistributive expenditure was being designed in order to present the state as credibly committed

\footnotetext{
1 Although the thrust of these fiscal reforms was broadly redistributive, it does not follow that the politics that inspired them was always left-wing: anti-poverty programmes have been expanded by the political right (in Colombia) and centre-right (in Mexico), as well as by the left and centre-left in Brazil, Bolivia, Ecuador, and Venezuela.

${ }^{2}$ Not all of these redistributive reforms have been sponsored by left-wing governments: for example, the right-wing Colombian government has sponsored a number of innovative social protection programmes.
} 
to fair dealing between different interest groups-and thereby to construct a more durable and stable political settlement, which would serve as a more secure framework for development programmes. In this paper we examine how well this objective was achieved, and what the implications of our findings are for researchers, policymakers, and aid donors. We proceed as follows. Section 2 offers a typology of how developing countries, rich and poor, have sought to escape from the tax trap, and the role of mineral export taxes in these strategies. In Section 3 we examine the crucial question of how these tax changes have been 'sold' to their political constituencies, and in this context describe the various forms in which social protection expenditure has been linked to measures of export taxation and the costs and benefits of these. In Section 4, with the help of case study material, we examine the political reaction to these measures, and whether and where they have helped to construct a more stable and durable political settlement. Section 5 draws the threads of the argument together.

\section{Linked progressive taxes as a redistribution strategy}

A major cause of global poverty is state failure, and a major element in state failure is inability to generate the public revenue required to finance the transformational expenditure programmes that are required for development. As Table 1 shows, this inability seems in many cases to be self-perpetuating in the poorer developing countries-over the last 20 or so years, the proportion of poorer countries that have managed to achieve significant increases in tax revenue is much lower than the proportion of richer countries that have done the same. The implication is that 'business as usual' is not capable of making development happen in poorer developing countries, which need to 'think outside the box' if they are to escape from the low-tax, lowexpenditure, low-growth poverty trap. 
Table 1: Developing countries: tax ratio dynamics (1990 to present)

\begin{tabular}{|c|c|c|}
\hline & $\begin{array}{l}\text { Low income(average tax } \\
\text { ratio }=13.2 \%)\end{array}$ & Middle income(average tax ratio $=19.3 \%$ ) \\
\hline $\begin{array}{l}\text { Numbers with static or } \\
\text { falling tax ratios }\end{array}$ & $\begin{array}{l}11 \text { (Burundi, }{ }^{*} \text { Cote d'Ivoire, } \\
\text { Democratic Republic of the } \\
\text { Congo, }{ }^{*} \text { Kyrgyz Republic, } \\
\text { Madagascar, Nicaragua, } \\
\text { Nigeria, Pakistan, Sri } \\
\text { Lanka, Yemen, Zimbabwe) }\end{array}$ & 4 (Jordan, Indonesia, Panama, Venezuela*) \\
\hline $\begin{array}{l}\text { Numbers with rising tax } \\
\text { ratios }\end{array}$ & $\begin{array}{c}9 \text { (Bangladesh, Bolivia, }{ }^{*} \\
\text { Ghana, }{ }^{*} \text { Nepal, Rwanda, } \\
\text { Sierra Leone, Uganda, }{ }^{*} \\
\text { Vietnam, Zambia*) }\end{array}$ & $\begin{array}{c}33 \text { (Argentina, }{ }^{*} \text { Botswana, Brazil, }{ }^{*} \text { Bulgaria, } \\
\text { Chile, }{ }^{*} \text { Colombia, China, Dominican } \\
\text { Republic, Ecuador, }{ }^{*} \text { Egypt, Fiji, Guatemala, } \\
\text { India, Iran, Jamaica, Kazakhstan, Lesotho, } \\
\text { Malaysia, Mexico, Morocco, Papua New } \\
\text { Guinea, Paraguay, Philippines, Peru, } \\
\text { Romania, Russia, Senegal, South Africa, } \\
\text { South Korea, Swaziland, Thailand, Tunisia, } \\
\text { Uruguay) }\end{array}$ \\
\hline $\begin{array}{l}\text { Trade taxes share of tax } \\
\text { revenue (average 1980- } \\
\text { 2009; percentage) }\end{array}$ & 22.1 & 11.5 \\
\hline $\begin{array}{l}\text { Aid/gross domestic product } \\
\text { (GDP) percentage (average } \\
\text { 1980-2009) }\end{array}$ & 11.1 & 4.0 \\
\hline
\end{tabular}

Notes: This is a revised and amended version of a table first published by one of the authors in Mosley (2015a). The numbers in each cell represents the absolute number of countries in each category.

'Rising tax ratios' denotes that the regression coefficient of tax effort (tax revenue/GDP) is significantly positive over the period 1990-2008. For 13 countries in our sample, no significant trend is observable. A 'middle-income' country is defined as a per capita income in excess of $\$ 1,000$ current dollars in 2009, and a 'low-income' country is defined as a country with a per capita income below that level. Countries marked with an asterisk ${ }^{*}$ are examined in greater detail below.

Source: authors' calculations, based on IMF, Government Expenditure Statistics, various issues; 58 observations, as listed.

Although there is evidence here of poor countries being caught in a low-income trap composed of political weakness, leading to excessive reliance on low-yielding trade taxes and lack of resources devoted to the generation of new revenue sources, leading to low expenditure and low income, what Table 1, especially its bottom left-hand corner, also illustrates is that the vicious circle of fiscal paralysis is one that can escaped. The nine countries in that bottom left-hand corner, although poor, have clearly found a way to achieve sustained increases in public revenue, in defiance of the obstacles mentioned above. How have they done it? And can other countries learn from their experiences?

We wish here to follow-up one particular strand of explanation within this puzzle, which is a decision by several countries during this period (some, but not all, of them 'bottom left-hand corner' countries) to move away from free-market neoliberal policies in pursuit of greater national autonomy, and as part of this process to impose a heavier rate of taxation on activities associated with higher-income groups (especially natural-resource exports). This approach potentially kills several birds with one stone-it increases revenue; it combats 'Dutch disease', which is the revaluation of the real exchange rate (and consequent competitive disadvantage) resulting from the accumulation of balance of payments surpluses derived from exports of natural resources; and it imposes some measure of restraint on environmental depletion. And it does all of this in an equity-increasing way, thereby subverting 'Director's Law' (Stigler 1970), which predicts that public expenditures will as a rule be primarily for the benefit of the middle 
classes, and yet financed with taxes borne by the poor and the rich, therefore distributionally regressive.

Table 2 illustrates this process and its relationship to the larger process of building a fiscal base for development. Among the nine countries in the bottom left-hand corner of Table 1, which escaped from the low-tax trap, five are natural-resource intensive (Uganda, Sierra Leone, Ghana, Zambia, and Bolivia), and all of these chose the natural-resource export tax route to escape from the low-tax, low-expenditure trap. In all of these cases this was by not only increasing the basic rate of corporation tax on mining and petroleum extraction, but also adjusting the rate of mineral royalties and, in the case of Ghana and Zambia, also imposing temporary windfall taxes. (In many cases they drew their inspiration from middle-income countries in the bottom right-hand corner of Table 1-such as Chile, Peru, and Ecuador-who also clearly perceived the political, as well as fiscal, payoffs to be derived from more effectively taxing their natural resources, and are included for comparison.)

However, among the countries in the 'poverty trap' group in the top left-hand corner of Table 1, none of the four which are natural-resource intensive (Democratic Republic of the Congo (DRC), Madagascar, Nigeria, and Zimbabwe) significantly increased the ratio of mineral taxation to GDP during the period under review. Particularly notorious in this group is the DRC, one of the most mineral-rich countries but also the poorest country in the world, which in spite of World Bank pressure continues to grant widespread tax exemptions that have very nearly wiped out the country's revenue base-including Gécamines, the state minerals company (Christian Aid et al. 2009: 41). The International Monetary Fund's (IMF) country report for Madagascar also draws attention to the correlation between its low-tax effort (on average less than 20 per cent over the last 20 years) and the fact that both its corporate tax rates and its royalty rates are 'towards the low end of the scale' (IMF 2014: 6, 12, 15, 24). The evidence points to these differences in mineral taxation policies as being one significant determinant of the ability of poor countries to achieve the fiscal space necessary for broad-based development, and in subsequent sections we shall explore the political-economy factors underlying these differences. 
Table 2: Taxes on minerals and hydrocarbons and overall tax ratios: 'low-income escapers' in relation to control group, 1990-2014

\begin{tabular}{|c|c|c|c|c|}
\hline Country & $\begin{array}{l}\text { Income } \\
\text { level } 2014 \\
\text { (US\$ per } \\
\text { capita) }\end{array}$ & $\begin{array}{l}\text { Mineral and hydrocarbon taxes: } \\
\text { reforms 1990-2013 }\end{array}$ & $\begin{array}{l}\text { Mineral and } \\
\text { hydrocarbon taxes: } \\
\text { share in GDP } \\
\text { (percentage) 1990- } \\
2013\end{array}$ & $\begin{array}{l}\text { Overall tax ratio } \\
\text { (percentage) } \\
\text { 1990-2013 }\end{array}$ \\
\hline \multicolumn{5}{|c|}{1 Bottom left-hand corner countries (escapers) } \\
\hline Uganda & 440 & $\begin{array}{l}\text { Corporate tax rate (for large } \\
\text { companies) } 30 \% \text {, payable by both } \\
\text { mineral and oil companies; small } \\
\text { companies taxed on a turnover basis. } \\
\text { Royalty } 3 \% \text { of total sales (since } 2003 \text { ). }\end{array}$ & $2 \rightarrow 5$ & $5 \rightarrow 16$ \\
\hline Sierra Leone & 580 & $\begin{array}{l}\text { Corporate tax rate } 25 \% \text { for residents, } \\
30 \% \text { for non-residents (but with many } \\
\text { exemptions); royalty } 25 \% \text { of gross } \\
\text { sales. Also a special tax on high-value } \\
\text { diamond exports (introduced in } 2000 \text {, } \\
\text { and raised from } 6 \% \text { to } 15 \% \text { in } 2009 \text { ). }\end{array}$ & $2 \rightarrow 6$ & $5 \rightarrow 12$ \\
\hline Ghana & 1,550 & $\begin{array}{l}\text { Minerals: corporation tax } 35 \%(25 \% \\
2006-11) ; \text { royalty } 3 \% 1990-2009(5 \% \\
\text { after 2010); windfall tax } 15 \%(2000-06 \\
\text { only). }\end{array}$ & $2 \rightarrow 6$ & $11 \rightarrow 21$ \\
\hline Zambia & 1,350 & $\begin{array}{l}\text { Minerals: increase in corporation tax } \\
\text { from } 25 \text { to } 30 \% \text { in } 2006 \text {; windfall } \\
\text { profits tax imposed, then withdrawn, } \\
2008-09 \text {; increase in royalty rates } \\
\text { from } 3 \text { to } 6 \% \text { in } 2011 \text {. }\end{array}$ & $1 \rightarrow 6$ & $19 \rightarrow 22$ \\
\hline Bolivia & 2,220 & $\begin{array}{l}\text { Hydrocarbons: supplementary profits } \\
\text { tax (IDH, see text), 2005; also } \\
\text { 'nationalization' (i.e. renegotiation) of } \\
\text { relationship with existing oil and gas } \\
\text { companies, involving higher rates of } \\
\text { tax on most profitable gas fields, } 2006 \text {. } \\
\text { Minerals: corporation tax rate } \\
\text { increased from } 25 \text { to } 37 \% \text {. }\end{array}$ & $0.4 \rightarrow 13$ & $7 \rightarrow 16$ \\
\hline $\begin{array}{l}\text { Sub-group } \\
\text { average }\end{array}$ & 1,228 & & $1.5 \rightarrow 7$ & $9 \rightarrow 17$ \\
\hline \multicolumn{5}{|c|}{2 Top left-hand corner countries (still in the low-tax, low-expenditure poverty trap) } \\
\hline $\mathrm{DRC}$ & 220 & $\begin{array}{c}\text { Minerals: corporation tax } 20 \% \text {, but } \\
\text { many illegal exemptions, including } \\
\text { Gécamines, the state mining } \\
\text { corporation, which pays no tax } \\
\text { revenue. }\end{array}$ & $1.5 \rightarrow 1$ & $4 \rightarrow 5$ \\
\hline Nigeria & 1,430 & $\begin{array}{l}\text { Profits tax } 20 \% \text {, plus natural-resource } \\
\text { rent tax (since 2005). }\end{array}$ & $5 \rightarrow 6$ & $10 \rightarrow 12$ \\
\hline Madagascar & 430 & $\begin{array}{l}\text { Corporate income tax rate reduced } \\
\text { from } 30 \% \text { in } 2007 \text { to } 20 \% \text { in } 2012 ; \\
\text { mineral royalties } 2 \% \text { of gross sales; } \\
\text { simplified tax regime for small } \\
\text { businesses. }\end{array}$ & $3 \rightarrow 2$ & $6 \rightarrow 9$ \\
\hline Zimbabwe & 680 & Profits tax rate $38 \%$; no royalty. & $0.6 \rightarrow 1.1$ & $19 \rightarrow 8$ \\
\hline $\begin{array}{l}\text { Sub-group } \\
\text { average }\end{array}$ & 615 & & $2.5 \rightarrow 2.5$ & $10 \rightarrow 8$ \\
\hline
\end{tabular}




\begin{tabular}{|c|c|c|c|c|}
\hline Peru & 5,880 & $\begin{array}{l}\text { Corporation tax rates raised from } 25 \text { to } \\
30 \% \text {; royalty imposed, dependent on } \\
\text { dollar export price. }\end{array}$ & $4.2 \rightarrow 14.5$ & $10 \rightarrow 15$ \\
\hline Brazil & 11,630 & $\begin{array}{c}\text { Corporation tax rates raised to } 33 \% ; \\
3 \% \text { royalty imposed. }\end{array}$ & $2.8 \rightarrow 3.8$ & $12 \rightarrow 17$ \\
\hline Venezuela & 12,470 & $\begin{array}{l}\text { Corporation tax (ISLR, see text) } 30 \% \text {, } \\
\text { plus } 3 \% \text { royalty on gross sales. }\end{array}$ & $3.5 \rightarrow 4$ & $10 \rightarrow 13$ \\
\hline Chile & 14,280 & $\begin{array}{l}\text { Corporation tax rate constant at } 15 \% \text {; } \\
\text { no royalty. }\end{array}$ & $4.0 \rightarrow 15.3$ & $14 \rightarrow 20$ \\
\hline $\begin{array}{l}\text { Sub-group } \\
\text { average }\end{array}$ & 11,065 & & $3.6 \rightarrow 9.4$ & $12 \rightarrow 16$ \\
\hline
\end{tabular}

Sources: Ghana, Zambia and Bolivia: individual country sources as reported in Mosley (2014a, 2014b; see also Mosley et al. 2015). Latin American countries (except Bolivia): mostly from IMF, International Financial Statistics, supplemented by Gomez Sabaini et al. (2015: tables 3, 5). African countries (except Ghana and Zambia); mostly from IMF, International Financial Statistics, supplemented by Fraser and Larmer (2010: table 3.1).

By moving away from a mindset which saw the price of taxing the multinationals as being automatic capital flight (and consequent political collapse), and grasping the mineral taxation nettle, the regimes which seized this opportunity were able to take important steps along the road towards fiscal autonomy. In particular, this enabled them, not only in Latin America, to expand their welfare systems: as argued by Bastagli (2015) and ourselves (Mosley 2015a), ${ }^{3}$ the level and mix of tax revenue are important determinants of the resources available for social protection systems and their sustainability over time.

Some escapers went beyond merely enlarging the fiscal space available to them, and were able to achieve export-based industrialization and long-term reductions in poverty; but not all were able to do this, and in later sections of the paper we explore which countries were and were not able to build on the fiscal space they created.

\section{Alternative forms of 'linked taxation' in Africa and Latin America}

In this paper we are concerned in particular to explore the performance of a subset of these 'bottom left-hand corner' countries, who were proactive not only in escaping from the low-tax, low-development trap, but also in thereby reducing poverty-in the short term principally through increases in social protection expenditure and other forms of pro-poor expenditure, and in the longer term by confronting special interest groups and increasing competitiveness. We consider these cases separately; the link to social protection is examined in this section, and the longer-term relationship with competitiveness and growth is examined in Section 4.

Table 3 presents an initial mapping of the forms in which administrations in Latin America and Africa have attempted to pursue the idea of progressive taxation linked to social protection. This has mainly happened in the twenty-first century. As the table shows, the idea originated in Bolivia through the linking, after 2004, of the IDH (Impuesto Directo en los Hidrocarburos or hydrocarbons income tax) to the Renta Dignidad universal old-age pension and Bono Juancito Pinto

\footnotetext{
${ }^{3}$ The paper by Mosley et al. (2015: tables 4 and 5) shows that tax structures and levels are not only correlated with, but positively and significantly influence, with a lag, the level of public expenditure and economic growth.
} 
primary education subsidy), and was also adopted in Ecuador (through earmarked allowances for social protection, expenditure in low-income provinces, and universities, financed from oil revenues from the late 1990s onward) and Venezuela (through the Misiones social welfare initiatives of the Chávez government from 2003 onwards, financed initially by a doubling of the ISLR petroleum income tax and then, after 2008, by a new tax on windfall incomes from hydrocarbons).

These three governments, as pointed out by Eaton (2013), have much in common politically, being not only left-leaning but also committed to a reversal of the policies of decentralization and regional devolution introduced with the support of Washington financial institutions as part of the liberalizing reforms of the 1990s. In all three administrations, most dramatically in Bolivia where the eastern province of Santa Cruz sought to secede from the national constitution in 2009 , the national-level expenditure programmes provided in the shape of social expenditures linked to petroleum taxes were used to counterbalance and cut back the power of the dissident regions in which the opposition had found political shelter (Eaton 2013: 421). It is understandable that, of the three countries, Bolivia is the one that has made the tightest link between petroleum taxation and pro-poor cash transfers, since it was there that, in 2003, a revolution against the neoliberal MNR (Movimiento Nacional Revolucionario) regime was triggered by violent protests against increasing levels of unemployment and poverty through the year, which were focused on the MNR's failure to effectively tax the hydrocarbons sector, and, in October of that year, against its murder of some 50 strikers who were blockading a petroleum depot in El Alto (Mosley 2012: chapter 12). Ecuador and Venezuela, in the early 2000s, were less acutely exposed to the charges of oppressing indigenous ethnic groups which brought about the Bolivian riots and reforms, but felt the pressure nonetheless, with the consequences recorded in Table 3.

When a couple of African governments that had also incurred political unpopularity through the manner in which they carried out liberalization-Zambia and Ghana-also ventured down the linked taxation route in the mid-2000s, they did it by a different route. Levy Mwanawasa's MMD (Movement for Multi-party Democracy) dominant-party government in Zambia faced, like Bolivia's MNR, with a challenge to the privileges of the mining corporations, particularly from the urban poor, ${ }^{4}$ elected in 2008 to impose a windfall tax at a rate of 25 per cent on gross proceeds, with 40 per cent of the revenue earmarked for spending on education, health, and other local council expenditures in the poorest districts of Zambia. This windfall tax was removed in 2009 by Mwanawasa's successor, nominally reintroduced in 2011 (although there is now no sign of the proceeds being allocated to social protection as in 2008), and in that year complemented by a doubling of the rate of mineral royalty from 3 per cent to 6 per cent (there was a further attempt to raise the royalty paid by the most profitable mines in January 2015, but this was abandoned after the mining corporations concerned-First Quantum and Barrick Gold-threatened to leave the country). Thus the target for linked progressive taxation in Zambia, as in the Latin American cases considered above, was the large mining corporations. There is some evidence that the design of the 2008 windfall tax was influenced by discussions during that year with the Chilean state copper-mining corporation CODELCO, which for many decades has contributed substantially to public revenue in a way that has been widely publicized in Chilean tax enforcement campaigns (Bergman 2003).

\footnotetext{
${ }^{4}$ Specifically, in the words of Cheeseman and Hinfelaar, from 'not so much those in full-time wage employment, but more radical mineworkers and the unemployed in Zambia's poorest urban compounds' (Cheeseman and Hinfelaar 2009: 77).
} 
The other case where linked progressive taxation has been attempted in Africa, namely Ghana, is quite different. The base for this linked taxation is much broader, consisting not only of mining corporations but also user charges and VAT, and the transmission channel by which the idea travelled there was not a Latin American agency of any kind, but the IMF, with whom the Ghanaian government has since the liberalizing reforms of the 1980s had a surprisingly comfortable, even an indulgent, relationship. ${ }^{5}$

During the early 2010s, Ghana also had a windfall tax on gold mining, initiated by the National Democratic Congress in 2011 but abandoned by them in 2014 (Abdulai, 2016); ${ }^{6}$ however, this tax was not earmarked for social protection or any other purpose and so we simply mention it in passing here. In Ghana, the taxes that have been linked to social protection are, first of all, a 'talk tax' on mobile phone usage imposed in 2004 (Prichard 2009: 25-27) and used to finance expenditures on reducing youth unemployment; and, much more substantially, national health insurance. Initially, in the late 1980s, the Ghanaian government financed health insurance payments under an IMF/World Bank Enhanced Structural Adjustment Facility, under what was known as the 'cash and carry' scheme, out of user charges on patients. However, this scheme became increasingly unpopular through the 1990s because it was regressive and inequitable. Under this system, in which patients were required to pay for their health needs at the point of service delivery, many people either failed to seek medical attention or delayed doing so because of the charges they were likely to face.

The cash and carry scheme was eventually replaced in 2004 by the then ruling NPP (New Patriotic Party) with a mandatory National Health Insurance Scheme (NHIS), which covers 95 per cent of the disease burden in Ghana and is principally financed by a 2.5 per cent levy added to the VAT on goods and services. In principle, VAT, as a tax base, is not as progressive as income tax, but like most developing countries Ghana does not yet have a wide-coverage income tax system, and it is certainly much more progressive than the previous mainstay of Ghana's public revenue, ${ }^{7}$ the heavy implicit taxes (deductions from the price paid to the farmer) on the export of cocoa, a largely smallholder crop, under which Ghana laboured from the 1930s to their partial abolition in 1992. The NHIS has had a major role in making politically feasible what one commentator describes as 'the most dramatic, and prolonged improvement in tax collection of any country in Africa' (Prichard 2009: 8). The key point about both of these reforms is that they were advertised to the public as a process by which both parts of the fiscal bargain, tax and expenditure, were being made fairer and more equitable - a process which the formal linking of those operations helped to highlight.

\footnotetext{
${ }^{5}$ Since the reforms of the 1980s, Ghana has barely been able to control its budget deficit or, as a consequence, its inflation rate. Its macroeconomic performance was classified by Adam and O' Connell in 2006 as being within the 'pre-stabilization' category, with inflation over 20 per cent at the beginning of the 2000s (Adam and O'Connell 2006: table 5.1). Exceptionally, the IMF overlooked these failings, noting that on even more fundamental issues, including tax and exchange-rate reform and policies for poverty reduction, Ghana was shaping up to be an outstanding performer - a trust which was amply rewarded. Between 1991 and 2014, Ghana's headcount poverty rate was more than halved (Ghana Living Standards Survey, 2015).

${ }^{6}$ A windfall tax on mining profits had previously been introduced by the PNDC in 1986 and then abolished by the pro-business NPP in 2006.

${ }^{7}$ It has been made more progressive especially by widespread exemptions granted to expectant mothers (JehuAppiah et al. 2011). However, Director's Law has made something of an appearance also, because the Ghana Trades Union Congress and the Ghana National Association of Teachers (GNAT) have been able to lobby successfully for exemption from paying workers' contributions to the Social Security and National Insurance Trust, even though informal-sector workers who have no access to trade union leverage still have to pay contributions to the trust.
} 
These five cases are the only administrations which, to our knowledge, formally earmark specific tax revenues for social protection purposes by means of a statutory legal instrument. However, as noted by Barrientos (2013), there are a number of administrations, particularly in Latin America, which although not engaging in formal earmarking nonetheless make a point of referring to specific tax initiatives as being explicitly for the purpose of social protection, and therefore supporting the overall cause of poverty reduction. The review by Barrientos (2013: 192-93) refers to the cases of Chile and Brazil (described in Table 3), and also Lesotho and Swaziland as supporting this kind of narrative. The case of the (Nestor) Kirchner administration in Argentina between 2002 and 2010 is particularly interesting as an administration that: implemented price control; reduced financial dependence on the World Bank and IMF; expanded social protection; and developed new tax bases, in particular export taxation. This was an integrated package of measures designed to achieve economic recovery and transformation without being reduced to chronic fiscal dependence on Northern institutions-an approach labelled in Argentina as neodesarollismo (neodevelopmentalism). ${ }^{8}$ Within this philosophy, the role of linked taxation was to reinforce political support for the state's expenditure plans by illustrating that their financing derived from a precious, non-renewable natural resource-oil and gas reserves-which historically had been undertaxed because of control by foreign (typically North American) interests (Grugel and Riggirozzi 2009) - in other words, sending a signal that linked taxation made the country a fairer place to live. Whether or not this signal 'works' is obviously key to its effectiveness.

\footnotetext{
${ }^{8}$ The idea of neodesarrollismo did not spread far outside Argentina, although it gained a certain amount of traction, as neodesenvolvimento, under the Lula administrations of 2000-08 in Brazil.
} 
Table 3: 'Linked' progressive taxation and its benefits

\begin{tabular}{|c|c|c|c|c|c|c|}
\hline \multirow[t]{2}{*}{ Country/product } & \multirow[t]{2}{*}{ Tax } & \multirow[t]{2}{*}{ Royalty } & \multirow[t]{2}{*}{ Other } & \multirow[t]{2}{*}{ Nature of linkage } & \multicolumn{2}{|c|}{ Benefits from linkage(and sources) } \\
\hline & & & & & Informal observations & Quantitative measure \\
\hline \multicolumn{7}{|c|}{1 Countries which formally link, or have linked, some elements of mineral taxation to social protection } \\
\hline \multicolumn{7}{|c|}{ Latin American cases } \\
\hline Bolivia & $\begin{array}{l}\text { Company profits tax } \\
\text { (Impuesto sobre las } \\
\text { Utilidades de las } \\
\text { Empresas, or IUE): } \\
25 \% \text { (paid only by large } \\
\text { mining companies and } \\
\text { not by cooperatives or } \\
\text { small mines) }\end{array}$ & $\begin{array}{l}\text { Regional-level } \\
\text { royalty: } 11 \% \\
\text { National royalty: } \\
6 \%\end{array}$ & $\begin{array}{l}\text { IDH: } 16 \% \\
\text { (increased to } \\
32 \% \text { in } 2005 \text { ) }\end{array}$ & $\begin{array}{l}81 \% \text { of Renta Dignidad } \\
\text { (universal old-age pension) } \\
\text { financed from IDH in } 2014 \\
\text { (initially } 100 \% \text { ); remainder } \\
\text { financed by privatized } \\
\text { corporations; see Table } 8 . \\
\\
81 \% \text { of Bono Juancito Pinto } \\
\text { (subsidy for school expenses, } \\
\text { including textbooks and } \\
\text { lunches) financed from IDH } \\
\text { proceeds in } 2014 \text {, remainder } \\
\text { from privatized corporations } \\
\text { and National Treasury; see } \\
\text { Table } 8 \text {. }\end{array}$ & $\begin{array}{l}\text { Many respondents } \\
\text { reported a significant } \\
\text { impact of the bonos (and } \\
\text { especially the Renta } \\
\text { Dignidad) on the well- } \\
\text { being of their own } \\
\text { household; others } \\
\text { remarked that their impact } \\
\text { on the government's well- } \\
\text { being was greater than the } \\
\text { impact on members of the } \\
\text { public.(see Table 5). }\end{array}$ & $\begin{array}{l}\text { (1) Evaluation by Escóbar Loza et } \\
\text { al. (2013) finds a significant impact } \\
\text { of bonos on consumption of lower- } \\
\text { income groups. } \\
\text { (2) We find a significant effect of } \\
\text { the bonos on the reduction of } \\
\text { political instability in Bolivia (see } \\
\text { Table } 5 \text { and page 19). }\end{array}$ \\
\hline Ecuador & Tax on net profits: $23 \%$ & $\begin{array}{c}12.5-18.5 \% \text { (of } \\
\text { gross value of } \\
\text { petroleum } \\
\text { production) }\end{array}$ & $\begin{array}{c}\text { Tax on } \\
\text { extraordinary } \\
\text { incomes: } 70 \%\end{array}$ & $\begin{array}{l}\text { (1) Elements of petroleum } \\
\text { income earmarked for } \\
\text { universities, social protection, } \\
\text { and expenditure in } \\
\text { 'backward', especially } \\
\text { Amazonian, provinces. } \\
\\
\text { (2)Tax-revenue-financed } \\
\text { bonds used to finance } \\
\text { conditional cash transfers via } \\
\text { human development bond } \\
\text { (Bono de Desarollo Humano) } \\
\text { (Montúfar 2009). }\end{array}$ & & \\
\hline Venezuela & $\begin{array}{l}\text { ISLR: increased from } \\
25 \% \text { to } 50 \% \text { in } 2003\end{array}$ & $\begin{array}{l}30 \% \text { of value of } \\
\text { production ( } 20 \% \\
\text { for natural gas) }\end{array}$ & $\begin{array}{c}\text { Tax on } \\
\text { 'exceptional' } \\
\text { prices }\end{array}$ & $\begin{array}{l}\text { Tax-linked bonds, funded } \\
\text { from the ISLR increase and } \\
\text { after } 2008 \text { by windfall taxes, } \\
\text { used to finance conditional } \\
\text { cash transfers (Montúfar } \\
\text { 2009). These transfers, under }\end{array}$ & $\begin{array}{l}\text { Percentage living in } \\
\text { extreme poverty fell from } \\
24 \% \text { in } 1990 \text { to } 9.4 \% \text { by } \\
2007 . \text { There was also 'a } \\
\text { growing body of evidence } \\
\text { that the Misiones and }\end{array}$ & \\
\hline
\end{tabular}




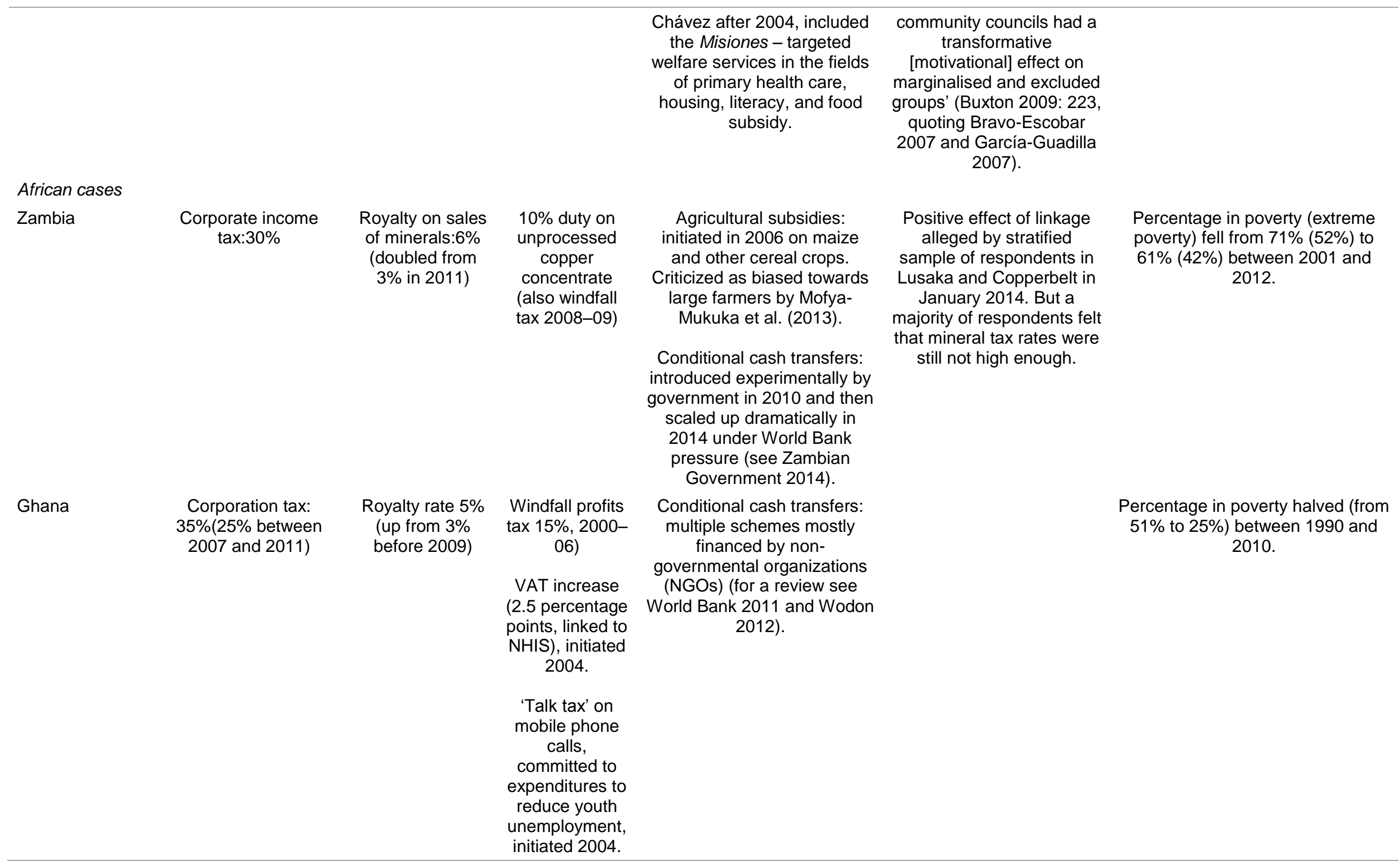


2 Countries which informally link some elements of mineral taxation to social protection

Chile

Tax on 'first-category'
incomes, $20 \%$ (will be

gradually raised to $25 \%$

in 2018)
None

\section{Tax on utility \\ profits $35 \%$ and}

dividends(4\%)

for public

enterprises;

special tax $40 \%$

on private utility

companies.

Lagos administration in 2002 ,
financed by increase of $2 \%$ in

tax burden distributed across

increase in corporate taxes,

personal income taxation,

and VAT). 'In particular, a $2 \%$

rise in the value-added tax

rate, from 16 to $18 \%$, was

explicitly linked to the

financing of (these) poverty

reduction programmes

(Barrientos 2013: 192).

Brazil

\begin{abstract}
Standard rate $15 \%$,
plus $10 \%$ surcharge on

incomes in excess of

$\mathrm{R} \$ 240,000$ per annum

$10 \%$ of value of

roduction (may

be reduced to

$5 \%$ in cases of

high geological

risk
\end{abstract}

Utility tax 15\%

The 1988 Constitution

created a new social contract, with explicit recognition of the right to social protection as a key principle, financed principally

by a $2 \%$ tax on agricultural sales (with the balance from social insurance funds) (Barrientos 2013: 193).
The Chile Solidario

programme "was a

reaction to the fact that

before 2002, all surveys were showing a fast

reduction in public support

for Lagos....The

programme was a

tremendous political hit'

(Puentes 2009).

Sources: Gomez Sabaini et al. (2015: table 2, p.36); column 5: Barrientos (2013: 191-94). 
The argument so far, then, is that governments which link social protection expenditures (or any other form of progressive public expenditure) to progressive forms of taxation such as mineral export taxation will secure a political dividend from a fairer public expenditure mix, ${ }^{9}$ because that makes the fiscal bargain more attractive to taxpayers and to the electorate in general. In addition, a great deal of evidence (e.g. Scholz and Lubell (1998) for the United States; more recently Bodea and Le Bas (2013) and Ali et al. (2014) for African countries) now suggests that evidence of better-targeted and more effective public spending helps to generate a firmer tax base and a firmer foundation for economic development. Our hypothesis, therefore, is that linked taxation will by this route improve political stability and increase tax ratios in developing countries, as per Figure 1.

Figure 1: Proposed estimating hypothesis

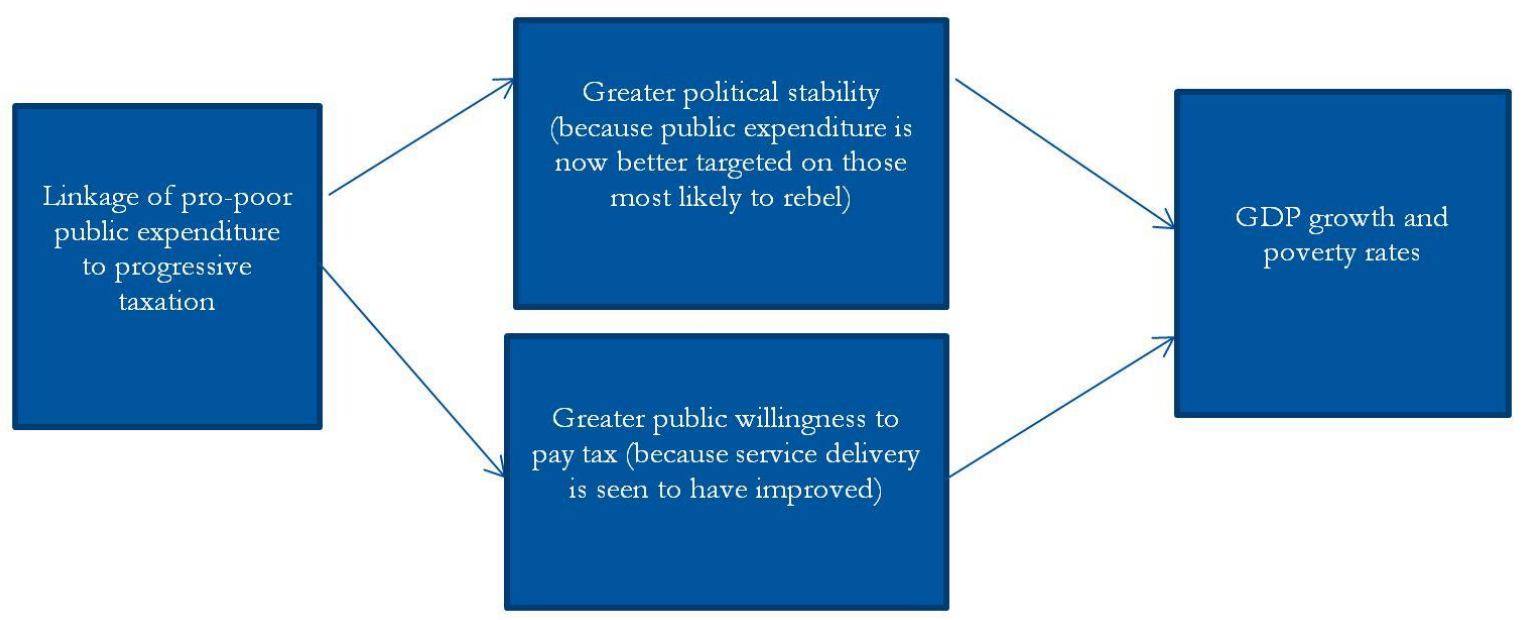

Source: authors.

Of course, even if these hypotheses are proved true, this is only the benefit side of the equation. The cost side is that linked progressive taxation, like every other interference with a 'competitive equilibrium', is likely to impose resource $\operatorname{costs}^{10}$ - for example, by giving a disincentive to the production of oil, minerals, or whatever is the base selected for linked taxation. That disincentive will increase, other things being equal:

- the more taxation is imposed on production (e.g. in the form of a royalty) rather than on net income or profits, as royalty-type taxes provide more of a disincentive to productivity and competitiveness in the taxed sector;

\footnotetext{
${ }^{9}$ The idea that a higher rate of taxation on petroleum and minerals generates a 'fairer' distribution of income and expenditure depends, of course, on the assumption that more tax, after reform, is paid by prosperous multinational corporations and their employees, and less tax is paid by poorer people. This assumption may or may not be true, it depends on whether the tax burden is shifted from multinational corporations on to others, and if so, whether these others are richer or poorer than the multinational corporations. This is notoriously hard to assess, but standard public finance analyses argue that corporation taxes 'will be shifted backward on to capital owners or forward on to employees' (Gemmell and Morrissey 2003: table 4; see also Gemmell and Morrissey 2005). All that is claimed here, with some empirical backing especially for Zambia and Bolivia, is that the electorate perceived increases in oil and mining taxes, and their linkage to new social protection measures, as being progressive and pro-poor (see the two right-most columns of Table 3), providing a bonus to the incumbent government.

10 This is noted by Prichard's essay on taxation in Ghana, which notes that 'earmarking and the segmenting of oversight authority is inconsistent with ... best practice in financial management' (Prichard 2009: 26).
} 
- the further the rate of taxation on natural-resource incomes gets out of line with the rate of taxation on other forms of income, as any kind of tax imposes a distortion, but, other things being equal, the distortion is minimized if tax rates can be kept uniform; and

- the more rigid is the linkage from natural-resource taxation to public expenditure, since in times of falling export prices for oil and other natural resources (such as 2008-09 and 2014-15) a rigid link between a particular form of social protection expenditure implies that such pro-poor expenditure must fall when the designated revenue source falls, which has an obvious social cost.

Thus, there is a tradeoff between the political gains and the economic losses which derive from linked export taxation. But, on the evidence already presented for Bolivia, Zambia, and Ghana, the political gains materialize quickly, whereas the economic costs take a long time even to be perceived. Also, it is possible to move the tradeoff by taking advantage of the propositions stated above. In the next section, we examine how, using this structure as a point of departure, it may be possible to best manage linked export taxation from a poverty-reduction point of view.

\section{The political economy of linked progressive taxation and social protection: ways forward}

\subsection{The shape of the tradeoff}

The efficiency-equity tradeoff inherent in linked export taxation is portrayed in Figure 2. Each administration, wishing to get as close as it can to the bottom right-hand corner of the diagram, will select its tax rate so as to optimize its welfare (e.g. this 'best feasible' point is reached at point A). However, as discussed above, various possibilities exist for 'moving the tradeoff to the south-east', that is, for increasing welfare without changing tax rates. 


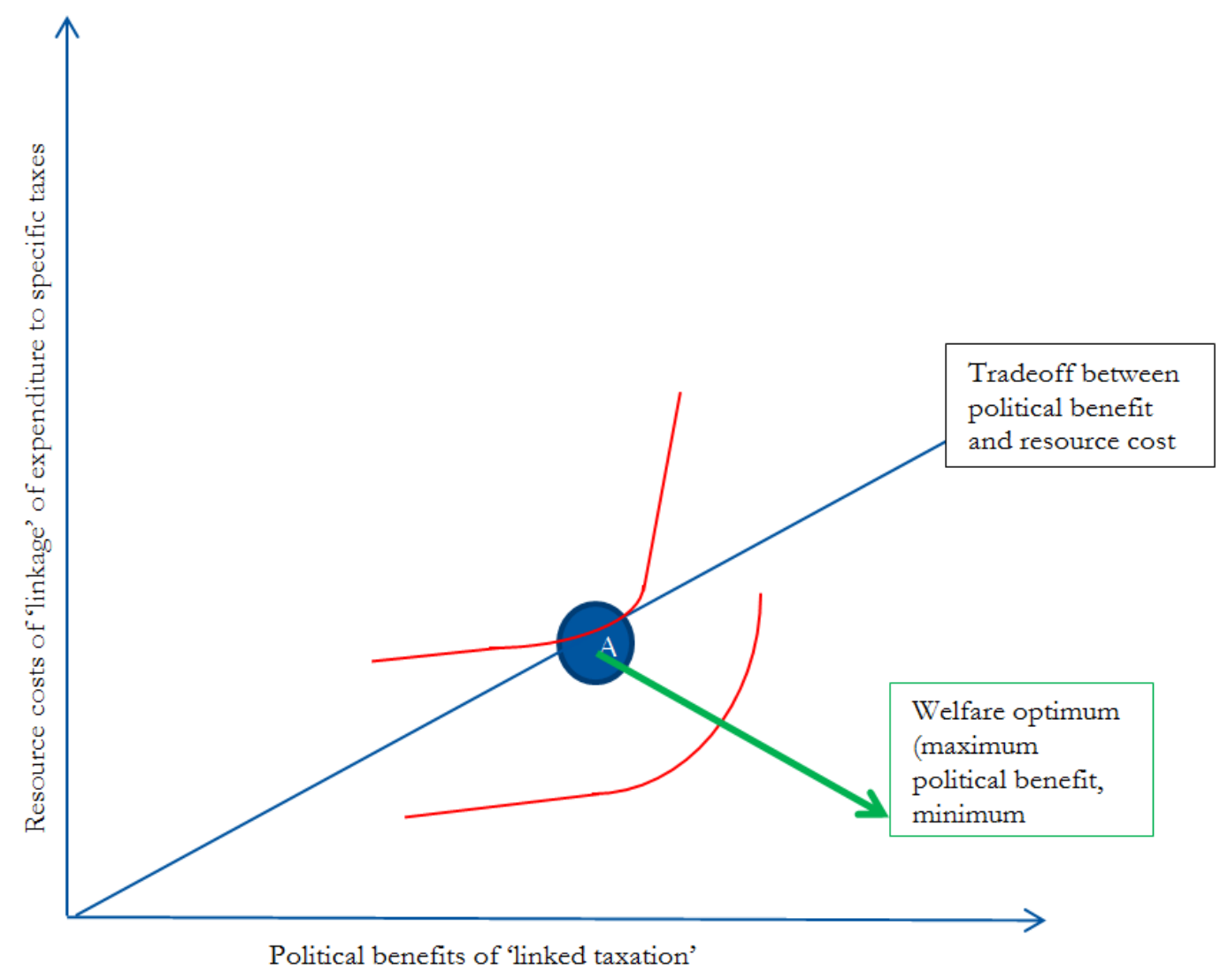

Source: authors.

First, on the tax side, the government may choose in case of need (for example, during a period of falling mineral export prices) to loosen the link between specific expenditures and measures of taxation by switching from one source of revenue to another (we shall observe some examples of this in the case of Bolivia, below). This will rescue the government from disappointed expectations caused by welfare payments declining with the value of the revenue base-a situation relevant at the time of writing (late 2016), when mineral prices have been weak for a considerable time.

Second, also on the tax side, the government can reduce fiscal rigidity and thus resource costs at no obvious damage to political support by moving from mineral taxes based on flat-rate royalties, which do not give an incentive to increase productivity, to taxes based on net income or profits, which do.

Third, on the expenditure side, the government can increase its appeal to target groups, and attempt to control political instability, by concentrating welfare benefits (and other forms of public expenditure) on the most militant and aggressive interest groups. Again we shall use Bolivia as an illustration of this principle, below. However, this may harm not only efficiency (i.e. take us northward in Figure 2) but also equity, as the most militant and best-organized protesters are not necessarily the poorest.

Bearing in mind these possibilities, and the ambiguities in the definition of an optimal fiscal policy, what scope is there for using linked taxation in a more effective way? 


\subsection{The political and economic gains from linked export taxation: the Bolivian case}

First, let us put the model of Figure 2 to the test, and examine what kind of political dividend from linked export taxation has in fact materialized. We shall begin with Bolivia, the pioneer in the field, and then expand the discussion to other countries.

The first thing we notice is that 'something happened' in the real economy at the same time that linked export taxation was introduced, in the mid-2000s. In particular, poverty levels, which the liberalizing governments of the 1985-2004 period had vainly been trying to tackle by means of increased health and education expenditures and the Emergency Social Fund, suddenly began to drop quite sharply after 2005 in response to the social reforms of the Morales period. This is illustrated by Figure 3 .

As shown in Figure 3, the downturn after 2004 in both headcount poverty and inequality, after a century of stasis with Bolivian poverty rates locked within the 60-65 per cent range, coincides with a sharp upturn in the ratio of social protection expenditure to total expenditure, and there is an acceleration of the fall in poverty after 2007 when the two social protection programmes which are linked to the IDH—the Renta Dignidad and Bono Juancito Pinto-come on stream. Correlation, of course, does not imply causation, and in order to explore causation, therefore, let us examine some relevant quantitative evidence from the studies of these two programmes which have so far been done, and then take the discussion forward by looking at qualitative and quantitative evidence of their impact on political stability. 
Figure 3: Bolivia: poverty and inequality in relation to measures of pro-poor expenditure

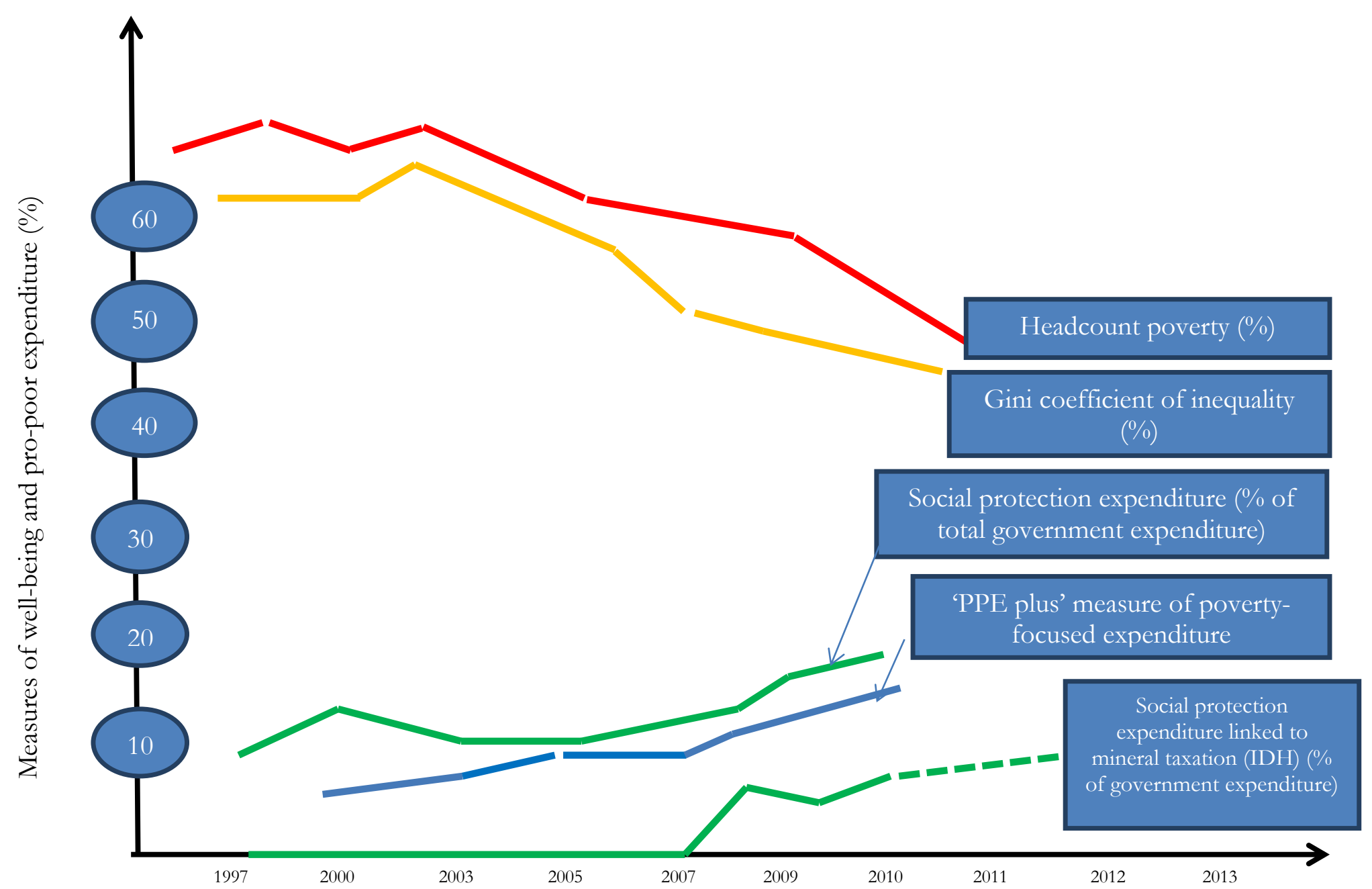

Source: authors, based on data from Mosley (2007: chapter 5). 
In relation to the Renta Dignidad, a study by UDAPE ${ }^{11}$ (Escóbar Loza et al. 2013), which draws on a 2011 study of households containing people over 60 years old conducted by the Instituto Nacional de Estadistica (INE) (the national statistical institute) finds, using regression methods, that the Renta Dignidad has: increased per capita household income by 165 bolivianos per month (US\$23) or 16.4 per cent of average income; increased per capita consumption by 154 bolivianos per month (US\$22) or 15.4 per cent; and reduced headcount extreme poverty by 156 bolivianos per month (US\$22) or 16.1 per cent. ${ }^{12}$ This impact is much stronger, however, in urban than in rural areas, and indeed is insignificant in rural areas in relation to all the variables mentioned above. These findings tally with findings on the effect of conditional cash transfers by Barrientos (2005) for Brazil and South Africa and by Altamar (2006) for Colombia. ${ }^{13}$ On the poverty impact of the bonos, findings are fewer; but UDAPE's report for the Millennium Development Goals (UDAPE 2013: figure 2) suggests that the Bonos Juancito Pinto and Juana Azurduy, between them, managed to lower extreme poverty between 1.5 and 2 per cent between 2006 and $2012 .^{14}$ This estimate is broadly confirmed by the study of the Bono Juancito Pinto by Arauco (2014), which finds also that the impact of the programme is progressive, benefiting 71 per cent of the extreme poor, 61 per cent of the poor, and 38 per cent of the non-poor (Arauco 2014: 19). In addition, the study by Canelas and Niño-Zarazua (2016) specifically examined whether the Bono improved school attendance, as it was intended to do, and concluded that it 'reduces [the incidence of paid work among beneficiaries of the programme] by one hour per week' (Canelas and Niño-Zarazua 2016: 1). Although we are less concerned here with the Bono Juana Azurduy because it is financed out of general revenue rather than mineral taxes, this also has been found to reduce poverty, by 2 percentage points over the four years it has been in operation-although, the authors modestly note, this is less than the impact achieved by Brazil and Uruguay with similar programmes (Arauco 2014: 24, 27, quoting Lustig et al. 2013 and Fuertes et al. 2015).

Let us now extend the discussion to other dimensions of impact and other countries. First, we examine the impact of linked taxation on political stability in Bolivia. We find (Table 4) that expenditure on the three new 'linked' social protection programmes (the Renta Dignidad, Bonos Juancito Pinto, and Juana Azurduy) had a significant negative impact on political instability as measured by the number of people killed or seriously injured in social conflicts over the period 1990-2014. The main finding is that linked social protection expenditure has had a significant (at the 10 per cent level) impact on political instability in Bolivia, measured either in terms of numbers killed in social conflicts (column 1) or in terms of number of days lost in strikes and demonstrations (column 4). It must be noted in passing that the question of how to measure political instability is contested, and that this result only holds if our own measures of political instability are used. If the rival estimate used by Roberto Laserna (2011) is used, which measures instability in terms of the number of civil conflicts (each of which is given equal weight), instability is on a rising trend since the change of regime in 2005, and the net impact of the

\footnotetext{
${ }^{11}$ Unidad de Análisis de Politica Economica: a government economic policy research unit attached to the Ministry of Finance.

12 Other estimates of impact exist: for example, Martínez et al. (2014) find that the Renta Dignidad programme reduced urban poverty (over what years is not specified) by 18 percentage points (Addison et al. 2016: 4).

13 Altamar (2006) found that the Proyecto de Atención para el Bienestar de la Persona Mayor raised income by approximately US\$34 per month. Barrientos (2005) found that in Brazil the Beneficio de Prestación Continua reduced the poverty gap from 59.4 per cent to 43.8 per cent- that is, by nearly 16 percentage points. In South Africa, Barrientos' finding was that the state pension reduced the likelihood of a person over 60 being in poverty by 12.5 per cent.

${ }^{14}$ This estimate was made by Fernando Landa of UDAPE, who decomposed household income between categories of income using data from the Instituto Nacional de Estadistica. He compared household consumption (between 2006 and 2012) between households who were or were not beneficiaries of one or more of the Renta Dignidad, Bono Juancito Pinto, and Bono Juana Azurduy (interview, Fernando Landa, 26 August 2014).
} 
linked taxation introduced at that time ('Instability 3 ' in column 6 of the table) is to increase the level of conflict!

Table 4: Determinants of political instability in Bolivia: regression-based estimates

\begin{tabular}{|c|c|c|c|c|c|c|}
\hline Equation & (1) & $(2)$ & (3) & $(4)$ & (5) & (6) \\
\hline Estimation method & 3SLS & 3SLS & 3SLS & 3SLS & 3SLS & OLS \\
\hline $\begin{array}{l}\text { Dependent } \\
\text { variable } \\
\text { Regression } \\
\text { coefficients on } \\
\text { independent } \\
\text { variables: }\end{array}$ & $\begin{array}{l}\text { 'Instability } \\
1 \text { ' = } \\
\text { numbers } \\
\text { killed in } \\
\text { social } \\
\text { conflicts }\end{array}$ & $\begin{array}{c}\text { 'Instability } \\
1 \text { ' = } \\
\text { numbers } \\
\text { killed in } \\
\text { social } \\
\text { conflicts }\end{array}$ & $\begin{array}{c}\text { 'Linked' } \\
\text { social } \\
\text { protection } \\
\text { expenditure } \\
\text { (Renta } \\
\text { Dignidad, } \\
\text { Bono } \\
\text { Juancito } \\
\text { Pinto, and } \\
\text { Bono Juana } \\
\text { Azurduy)as } \\
\text { percentage } \\
\text { of total } \\
\text { expenditure }\end{array}$ & $\begin{array}{l}\text { 'Instability } \\
2 \text { ' = number } \\
\text { of working } \\
\text { days lost in } \\
\text { strikes, } \\
\text { demonstrati } \\
\text { ons, and } \\
\text { other social } \\
\text { conflicts }\end{array}$ & $\begin{array}{c}\text { 'Linked' } \\
\text { social } \\
\text { protection } \\
\text { expenditure } \\
\text { (Renta } \\
\text { Dignidad, } \\
\text { Bono } \\
\text { Juancito } \\
\text { Pinto, and } \\
\text { Bono Juana } \\
\text { Azurduy) as } \\
\text { percentage of } \\
\text { total } \\
\text { expenditure }\end{array}$ & $\begin{array}{c}\text { 'Instability 3' } \\
=\text { number of } \\
\text { conflicts }\end{array}$ \\
\hline Constant & $\begin{array}{c}-172.77^{*} \\
(1.87)\end{array}$ & $\begin{array}{c}-188.5^{\star} \\
(1.89)\end{array}$ & $\begin{array}{c}0.49^{\star \star \star} \\
(9.47)\end{array}$ & & $\begin{array}{c}0.45^{\star \star \star} \\
(8.62)\end{array}$ & $\begin{array}{l}55.50 \\
(0.13)\end{array}$ \\
\hline GDP growth & $\begin{array}{l}-1.72 \\
(0.54)\end{array}$ & $\begin{array}{l}-3.60 \\
(0.78)\end{array}$ & & $\begin{array}{l}-20.7 \\
(1.28)\end{array}$ & & $\begin{array}{c}7.22 \\
(0.35)\end{array}$ \\
\hline $\begin{array}{l}\text { Gini coefficient of } \\
\text { inequality }(\%)\end{array}$ & $\begin{array}{l}3.17^{* *} \\
(2.50)\end{array}$ & $\begin{array}{l}3.44^{*} \\
(1.64)\end{array}$ & & $\begin{array}{l}69.0^{\star *} \\
(2.34)\end{array}$ & & $\begin{array}{c}3.54 \\
(0.58)\end{array}$ \\
\hline $\begin{array}{l}\text { Social protection } \\
\text { expenditure (\% of } \\
\text { total public } \\
\text { expenditure) }\end{array}$ & & $\begin{array}{l}-3.10^{\star} \\
(1.69)\end{array}$ & & & & $\begin{array}{c}22.86^{* *} \\
(3.28)\end{array}$ \\
\hline $\begin{array}{l}\text { 'Linked' social } \\
\text { protection } \\
\text { expenditure } \\
\text { (Renta Dignidad, } \\
\text { Bono Juancito } \\
\text { Pinto, and Bono } \\
\text { Juana Azurduy) as } \\
\text { percentage of total } \\
\text { expenditure }\end{array}$ & $\begin{array}{l}-24.4^{*} \\
(1.88)\end{array}$ & $\begin{array}{c}-74.97 \\
(1.02)\end{array}$ & & $\begin{array}{c}-411.5^{\star} \\
(1.62)\end{array}$ & & \\
\hline $\begin{array}{l}\text { Military centrality } \\
\text { (share of military } \\
\text { and police as } \\
\text { percentage of total } \\
\text { government } \\
\text { expenditure) }\end{array}$ & $\begin{array}{c}5.80 \\
(0.26)\end{array}$ & $\begin{array}{l}21.39 \\
(1.19)\end{array}$ & & $\begin{array}{c}0.82 \\
(0.40)\end{array}$ & & $\begin{array}{c}-77.44 \\
(0.84)\end{array}$ \\
\hline $\begin{array}{l}\text { Polity } 4 \text { index of } \\
\text { institutional } \\
\text { capacity }\end{array}$ & $\begin{array}{l}-0.99 \\
(0.85)\end{array}$ & & & $\begin{array}{l}-1.05 \\
(0.29)\end{array}$ & & \\
\hline $\begin{array}{l}\text { Budget surplus or } \\
\text { deficit }\end{array}$ & & & $\begin{array}{c}0.084^{* * *} \\
(7.57)\end{array}$ & & $\begin{array}{c}0.084^{* * *} \\
(7.57)\end{array}$ & \\
\hline $\mathrm{R}^{2}$ & 0.33 & 0.26 & 0.26 & 0.37 & 0.39 & 0.63 \\
\hline $\begin{array}{l}\text { Number of } \\
\text { observations }\end{array}$ & 23 & 23 & 23 & 23 & 23 & 23 \\
\hline
\end{tabular}

Estimation method: 3SLS. Period of estimation: annual data 1990-2013. Student's t-statistics in parentheses below coefficients. ${ }^{* *}$ denotes significance of a coefficient at the 1 per cent level, ${ }^{* *}$ at the 5 per cent level and ${ }^{* * *}$ at the 10 per cent level.

Sources: for dependent variables: 
'Instability 1' (number of persons killed). From our own data-set for 1979-2007, updated by the author: available from www.poverty.group.shef.ac.uk or from the author.

'Instability 2' (days lost in conflicts). From our own data-set for 1979-2007, updated by the author: available from www.poverty.group.shef.ac.uk or from the author.

'Instability 3' (number of conflicts). Original data from CERES, Observatorio de Conflictos. Data from 1990-2004 are presented in Laserna (2011), and I am grateful to Roberto Laserna for discussions.

For independent variables, all data are from Bolivia, INE, Anuario Estadistico 2012, and updates of these series from the INE website www.ine.gob.bo, except the data for 'linked social protection expenditure' (row 6) which are from Mosley (2017: table 5.6), and the polity index of institutional capacity, which is from www.systemic peace.org.

In the light of these findings, it is interesting also to examine qualitative interview evidence concerning the effect of the bonos, which is provided in Table 5.

Table 5: Respondents' views on public spending and 'earmarked' social protection measures

\begin{tabular}{|c|c|c|c|}
\hline & $\begin{array}{c}\text { Renta Dignidad } \\
\text { (non-contributory state } \\
\text { pension) }\end{array}$ & $\begin{array}{l}\text { Bono Juancito Pinto } \\
\text { (conditional cash } \\
\text { transfers for } \\
\text { schoolchildren) }\end{array}$ & $\begin{array}{l}\text { Bono Juana Azurduy } \\
\text { (conditional cash transfers for } \\
\text { expectant mothers and } \\
\text { mothers of new-borns) }\end{array}$ \\
\hline $\begin{array}{l}\text { Percentage of } \\
\text { respondents with a } \\
\text { beneficiary within the } \\
\text { household }\end{array}$ & 50 & 24 & 23 \\
\hline $\begin{array}{l}\text { Average overall change } \\
\text { in bond value (US } \$ \text { ) } \\
\text { recommended by } \\
\text { recipients }\end{array}$ & $\begin{array}{l}+ \text { US } \$ 58 / \text { month }(31 \% \text { of } \\
\text { recipients in support) }\end{array}$ & $\begin{array}{l}+ \text { US } \$ 65 / \text { month }(31 \% \text { of } \\
\text { recipients in support) }\end{array}$ & $\begin{array}{l}\text { +US } \$ 64 / \text { month }(24 \% \text { of } \\
\text { recipients in support) }\end{array}$ \\
\hline $\begin{array}{l}\text { Impact on economic } \\
\text { stability: summary of } \\
\text { views of recipients }\end{array}$ & $\begin{array}{l}\text { A majority of respondents } \\
\text { felt the impact was } \\
\text { positive, but some felt the } \\
\text { impact was short-term } \\
\text { only, and some felt that it } \\
\text { was actually counter- } \\
\text { productive-see } \\
\text { discussion below. } \\
\text { Others, such as } \\
\text { respondent } 3 \text {, felt that the } \\
\text { Renta should be made } \\
\text { more progressive-for } \\
\text { example, it should be } \\
\text { increased in respect of } \\
\text { the most vulnerable only. }\end{array}$ & $\begin{array}{l}\text { Most felt the impact was } \\
\text { on balance positive, but } \\
\text { some felt the bond } \\
\text { should be paid in cash } \\
\text { rather than as an } \\
\text { electronic transfer, and } \\
\text { one respondent } \\
\text { (respondent 3, see } \\
\text { below) felt that the Bono } \\
\text { was not successful at } \\
\text { reducing truancy even in } \\
\text { the short term. }\end{array}$ & $\begin{array}{l}\text { Most felt that the effect was on } \\
\text { balance positive, but some } \\
\text { respondents reported perverse } \\
\text { effects-for example, } \\
\text { respondent } 1 \text { suggested that } \\
\text { women were incentivized to } \\
\text { have additional children on } \\
\text { account of the Bono (see } \\
\text { below). }\end{array}$ \\
\hline $\begin{array}{l}\text { Relevance of linkage } \\
\text { between hydrocarbons } \\
\text { income and social } \\
\text { protection: summary of } \\
\text { views of recipients }\end{array}$ & $\begin{array}{l}\text { Most respondents thought } \\
\text { the link positive and was } \\
\text { politically valuable. }\end{array}$ & $\begin{array}{l}\text { Most respondents } \\
\text { thought the link positive, } \\
\text { but some respondents } \\
\text { (e.g. respondent 3) } \\
\text { thought the link was } \\
\text { 'purely symbolic'. }\end{array}$ & \\
\hline
\end{tabular}

Source: Survey, August 2014. The sample was carried out on a randomly chosen sample of 48 respondents, evenly divided between La Paz and El Alto on the western Bolivian altiplano. In each of the two cities, the sample was stratified between equal numbers of males and females and between four occupational groups: public and private sector professionals, manual formal-sector workers, and informal-sector workers. 
In relation to all of the bonds, many recipients, especially in the professional group, supported the quantitative evidence of Table 4 suggesting that the impact of the Renta Dignidad on political stability was positive (e.g., respondent 3 (professional, La Paz), who stated that the bonds 'have stabilized and calmed people' and respondent 4 (professional, La Paz), who stated that political stability in Bolivia had improved 'because the State is using natural resources to satisfy people's economic needs', thereby suggesting that it was the connection between natural-resource taxation and social protection, rather than social protection on its own, which was helping to make the country more stable).

However, a majority of respondents felt that in spite of this, the level of political stability in Bolivia had declined since 2009, which is in conflict with the quantitative evidence; also, a number of respondents felt that the design of the bonds could be improved. Several of them, especially in the manual worker sub-group, suggested that the bonds were a short-term fix (in Spanish, palliativo) that was good for the government but not for the country. This actual phrase was used, unprompted, by respondents 25 (miner, El Alto), 31(retired pastrycook, La Paz), and 39 (student, El Alto).

Some respondents suggested, probably correctly, that the motivation behind the programmes was principally political. For example, respondent 13 (professional male, 40, El Alto) remarked: 'It has helped the government protect itself, but it has not tackled the problem at its root.' Some respondents went further than this, and suggested that the bonds might have disincentive (or perverse) effects even in the short term. Respondent 3 (professional female, 28, El Alto) suggested that the Bono Juancito Pinto 'was not achieving its fundamental objective of reducing truancy', and respondent 1 (male, 38, informal sector, El Alto) suggested that women 'were having additional children' as a consequence of the incentive provided by the Bono Juana Azurduy. More vaguely, suggestions were made that the Renta Dignidad encouraged a 'beggar mentality' and 'involved a waste of resources' (e.g., respondents 6, 7, and 16).

In Table 6 we present panel-data regressions illustrating the effect of linked taxation on political stability and tax revenue compared across the range of countries discussed in Table 3. In column 1 of the table, the impact of linked taxation on political instability (measured as the degree of conflict in a country), estimated by OLS, emerges as significant at the 10 per cent level across this sample of countries. In column 2 of the table, we estimate the impact of linked taxation on the overall tax ratio both by OLS; in columns 3 through 6 we trace the entire chain of causation from linked progressive taxation through to the expenditure ratio to the growth and poverty outcome (as in Figure 1), using, in the last of those equations, population and lagged 1988 values of gross national product (GNP) per capita as instruments for overseas aid. In this equation system, a higher tax ratio increases public expenditure (Equation 4), which (Equation 5) increases growth and reduces poverty. Linked taxation is a significant determinant of the tax ratio (at the 5 per cent level) in both the OLS and 3SLS models and thus, in our interpretation, plays a part in state-building through its ability initially to build and diversify the tax base, thence public expenditure, and thence investment and growth. 
Table 6: Impact of the tax ratio on political instability and tax capacity: regression-based estimates

\begin{tabular}{|c|c|c|c|c|c|c|}
\hline Equation & (1) & $(2)$ & (3) & (4) & (5) & (6) \\
\hline Estimation method & OLS & OLS & 3SLS & 3SLS & 3SLS & $3 S L S$ \\
\hline $\begin{array}{l}\text { Dependent variable } \\
\text { Regression } \\
\text { coefficients on } \\
\text { independent } \\
\text { variables: }\end{array}$ & $\begin{array}{l}\text { Incidence } \\
\text { of conflict }{ }^{b}\end{array}$ & $\begin{array}{l}\text { Tax/GDP } \\
\text { ratio }\end{array}$ & $\begin{array}{l}\text { Tax/GDP } \\
\text { ratio }\end{array}$ & $\begin{array}{l}\text { Total } \\
\text { expenditure/GDP } \\
\text { ratio }\end{array}$ & $\begin{array}{c}\text { Poverty } \\
\text { headcount }\end{array}$ & Aid/GNP \\
\hline Constant & $\begin{array}{c}0.19 \\
(1.28)\end{array}$ & $\begin{array}{c}23.11^{\star * *} \\
(5.82)\end{array}$ & $\begin{array}{c}25.14^{\star \star \star} \\
(5.98)\end{array}$ & $\begin{array}{l}-3.46 \\
(0.46)\end{array}$ & $\begin{array}{c}-12.11 \\
(0.64)\end{array}$ & $\begin{array}{c}21.11^{* * *} \\
(13.93)\end{array}$ \\
\hline $\begin{array}{l}\text { 'Linked' taxation } \\
\text { dummy variable }\end{array}$ & $\begin{array}{c}-0.037^{*} \\
(1.75)\end{array}$ & $\begin{array}{l}2.38^{* *} \\
(2.31)\end{array}$ & $\begin{array}{l}2.12^{* *} \\
(2.12)\end{array}$ & & & \\
\hline $\begin{array}{l}\text { Gini coefficient of } \\
\text { inequality }(\%)\end{array}$ & $\begin{array}{l}-0.0027 \\
(1.48)\end{array}$ & $\begin{array}{l}-0.14 \\
(1.72)\end{array}$ & & & & \\
\hline $\begin{array}{l}\text { Share of trade taxes } \\
\text { to total revenue }\end{array}$ & $\begin{array}{c}-0.002 \\
(1.33)\end{array}$ & & & & & \\
\hline $\begin{array}{l}\text { Public expenditure } \\
\text { on health and } \\
\text { education (as } \\
\text { percentage of total } \\
\text { expenditure) }\end{array}$ & & $\begin{array}{l}-0.19 \\
(1.31)\end{array}$ & $\begin{array}{l}-0.32^{\star *} \\
(2.27)\end{array}$ & & & \\
\hline Tax/GDP ratio & & & & $\begin{array}{l}1.67^{\star * *} \\
(3.54)\end{array}$ & & \\
\hline Aid/GDP ratio & & & & & $\begin{array}{c}2.61^{* * *} \\
(9.40)\end{array}$ & \\
\hline GDP growth & & & & & $\begin{array}{l}-0.16^{\star \star} \\
(2.25)\end{array}$ & \\
\hline $\begin{array}{l}\text { Total } \\
\text { expenditure/GDP } \\
\text { ratio }\end{array}$ & & & & & $\begin{array}{l}-0.29^{*} \\
(1.74)\end{array}$ & \\
\hline Population & & & & & & $\begin{array}{l}0.073^{\star * *} \\
(3.19)\end{array}$ \\
\hline $\begin{array}{l}\text { GNP per capita in } \\
1988\end{array}$ & & & & & & $\begin{array}{l}-0.016^{\star \star \star} \\
(7.94)\end{array}$ \\
\hline $\mathrm{R}^{2}$ & 0.04 & 0.28 & 0.44 & 0.17 & 0.59 & 0.73 \\
\hline $\begin{array}{l}\text { Number of } \\
\text { observations }\end{array}$ & 75 & 44 & 31 & 31 & 31 & 31 \\
\hline
\end{tabular}

Notes:

Sample: Countries in which 'linked' taxation has been used: Bolivia, Ecuador, Venezuela, Zambia, Ghana, Mauritius (see Table 3 for more details).

a 'Linked export taxation' is a 1-0 dummy variable taking the value 1 during the years linked taxation was in force and 0 at other times.

$\mathrm{b}$ Incidence of conflict is measured by means of the World Bank ucdp_loc measure (see www.qog.gu.se which allocates a value of 3 to situations of severe conflict, 2 to moderate conflict, 1 to minor conflict and 0 to no or insignificant conflict.

${ }^{* \star *},{ }^{* \star},{ }^{*}$ denote significance at the 1 per cent, 5 per cent, and 10 per cent levels respectively.

Source: World Bank, Global Development Indicators database.

These regressions suggest that, across a range of countries, linked progressive taxation has yielded political and governance benefits, which in turn feed into growth and poverty reduction. But what of the costs: what are they, and how can they be minimized? 


\subsection{The economic losses from linked taxation, and how to mitigate them}

Several studies of the losses to productivity from progressive taxation have been done, including two by ourselves, for Bolivia and Zambia (Mosley 2014a, 2014b; see also Oporto et al. (2012) for Bolivia; Oxford Policy Management (2014) for Zambia). These estimates differ sharply by type of economy-in particular, countries such as Bolivia and Ghana, which have a large artisanal, or cooperative, mining sector, have tended to experience a larger fall in productivity over the last ten years than countries operating along a much more rigid production function, as is characteristic of oil-based economies such as Ecuador and Venezuela. (By contrast, the former type of economy has tended to generate larger increases in employment, and often greater improvements in equity as well. $)^{15}$

However, as illustrated in Table 7, the expectation that natural-resource intensive countries, in order to maximize revenue, would move away from 'efficient' forms of taxation (such as corporate income taxes) which tax profits rather than gross income, and thereby impose an additional efficiency cost on mining and oil companies, is not borne out by the data. Between 2000-03 and 2010-13, the ratio of revenue derived from 'more distortive' royalties to total revenue declines in the core 'linked export taxation' cases from 45 per cent to 39 per cent. In the 'informal linked taxation cases', such as Brazil and Chile, similarly, the proportion of total tax revenue derived from royalties declined from 56 per cent to 45 per cent. It therefore appears, prima facie, that the expected shift from 'more efficient' to 'less efficient' mineral taxes consequential on efforts to drive up revenue did not materialize.

15 For example, the mining sector of Bolivia between 2011 and 2013 has experienced an 18 per cent fall in productivity, but a 13 per cent increase in employment (see Mosley 2014b: 33, figure 4). 
Table 7: Hydrocarbon and mineral taxes: allocation between types of duties 2000-13 (percentages of total)

\begin{tabular}{|c|c|c|c|c|}
\hline & Instrument & 2000-03 & 2005-08 & $2010-13$ \\
\hline \multicolumn{5}{|c|}{ Core 'linked taxation’ cases } \\
\hline Bolivia & $\begin{array}{c}\text { Corporate income } \\
\text { taxes (CITs) } \\
\text { Royalties } \\
\text { Other }\end{array}$ & $\begin{array}{c}5.2 \\
94.8 \\
0\end{array}$ & $\begin{array}{l}6.9 \\
35.8 \\
57.3\end{array}$ & $\begin{array}{l}5.2 \\
34.3 \\
60.4\end{array}$ \\
\hline Ecuador & $\begin{array}{l}\text { ClTs } \\
\text { Royalties } \\
\text { Other }\end{array}$ & $\begin{array}{c}0 \\
0 \\
100\end{array}$ & $\begin{array}{c}0 \\
0 \\
100\end{array}$ & $\begin{array}{c}0 \\
0 \\
100\end{array}$ \\
\hline Venezuela & $\begin{array}{l}\text { CITs } \\
\text { Royalties } \\
\text { Other }\end{array}$ & $\begin{array}{l}19.8 \\
53.2 \\
27.0\end{array}$ & $\begin{array}{c}25.1 \\
68.8 \\
6.0\end{array}$ & $\begin{array}{l}11.0 \\
36.6 \\
52.4\end{array}$ \\
\hline Ghana & $\begin{array}{c}\text { CITs } \\
\text { Royalties } \\
\text { Other, incl. windfall } \\
\text { taxes }\end{array}$ & $\begin{array}{l}24 \\
45 \\
31\end{array}$ & $\begin{array}{l}15 \\
54 \\
31\end{array}$ & $\begin{array}{c}22 \\
70 \\
8\end{array}$ \\
\hline Zambia & $\begin{array}{c}\text { CITs } \\
\text { Royalties } \\
\text { Other, incl. windfall } \\
\text { taxes }\end{array}$ & $\begin{array}{c}65 \\
35 \\
0\end{array}$ & $\begin{array}{l}55 \\
25 \\
20\end{array}$ & $\begin{array}{c}46 \\
54 \\
0\end{array}$ \\
\hline Sub-group average & $\begin{array}{c}\text { CITs } \\
\text { Royalties } \\
\text { Other, incl. windfall } \\
\text { taxes }\end{array}$ & $\begin{array}{l}23 \\
45 \\
32\end{array}$ & $\begin{array}{l}21 \\
36 \\
43\end{array}$ & $\begin{array}{l}17 \\
39 \\
44\end{array}$ \\
\hline \multicolumn{5}{|c|}{ Informal 'linked taxation’ cases } \\
\hline Argentina & $\begin{array}{l}\text { ClTs } \\
\text { Royalties } \\
\text { Other }\end{array}$ & $\begin{array}{l}29.7 \\
59.6 \\
10.7\end{array}$ & $\begin{array}{l}34.3 \\
33.0 \\
32.7\end{array}$ & $\begin{array}{l}23.9 \\
38.4 \\
37.7\end{array}$ \\
\hline Brazil & $\begin{array}{c}\text { CITs } \\
\text { Royalties } \\
\text { Other }\end{array}$ & $\begin{array}{l}34.1 \\
27.4 \\
38.5\end{array}$ & $\begin{array}{l}38.3 \\
24.8 \\
36.9\end{array}$ & $\begin{array}{l}21.9 \\
34.0 \\
44.1\end{array}$ \\
\hline Peru & $\begin{array}{c}\text { CITs } \\
\text { Royalties } \\
\text { Other }\end{array}$ & $\begin{array}{c}15.4 \\
84.6 \\
0\end{array}$ & $\begin{array}{c}24.1 \\
75.9 \\
0\end{array}$ & $\begin{array}{c}26.1 \\
73.9 \\
0\end{array}$ \\
\hline Colombia & $\begin{array}{c}\text { CITs } \\
\text { Royalties } \\
\text { Other }\end{array}$ & $\begin{array}{l}19.6 \\
53.3 \\
27.0\end{array}$ & $\begin{array}{l}\mathbf{2 1 . 3} \\
47.0 \\
31.7\end{array}$ & $\begin{array}{l}29.0 \\
36.3 \\
34.7\end{array}$ \\
\hline Sub-group average & $\begin{array}{c}\text { ClTs } \\
\text { Royalties } \\
\text { Other }\end{array}$ & $\begin{array}{l}24 \\
56 \\
20\end{array}$ & $\begin{array}{l}29 \\
45 \\
25\end{array}$ & $\begin{array}{l}25 \\
45 \\
30\end{array}$ \\
\hline $\begin{array}{l}\text { Developing } \\
\text { countries average }\end{array}$ & $\begin{array}{c}\text { CITs } \\
\text { Royalties } \\
\text { Other }\end{array}$ & $\begin{array}{l}24 \\
50 \\
26\end{array}$ & $\begin{array}{l}25 \\
40 \\
35\end{array}$ & $\begin{array}{l}21 \\
42 \\
37\end{array}$ \\
\hline
\end{tabular}

Source: all Latin American countries: Gomez Sabaini et al. (2015: 47, table 4). Ghana: estimated from Mosley (2015b: 8, table 2). Zambia: estimated from Mosley (2014a: 12, table 3).

However, against this general trend we may note a discrepancy between the behaviour of the Latin American and African 'linked taxation' cases. In Latin America, consistently with the general trend, the ratio of royalty income to total revenue declines, but in the two African cases, Ghana and Zambia, it goes up substantially (from 40 per cent to 62 per cent), in spite of an increase in corporate income tax rates in both countries. In both countries, also, there was a politically popular experiment with windfall taxation of mineral exports in the mid-2000s (classed as 'other sources of revenue' in Table 7), which, however, was transient and failed to last. 


\subsection{Adaptations of revenue source}

Ever since the 2008-12 recession, and more particular since the weakening of Chinese growth in 2015, mineral exporters everywhere have been faced by a new threat: falling export prices, which of course drag down revenue in those forms of linked taxation regime that are based on exports. However, this problem can be confronted, as illustrated by the case of Bolivia, the pioneer of linked progressive taxation. At the inception of the Renta Dignidad and the Bono Juancito Pinto in 2006, both forms of social protection were 100 per cent financed by the special hydrocarbons tax, the IDH. However, with the onset of the global recession in 2009, a part of the financing of both income sources was (as can be seen in Table 8) transferred to the National Treasury. In the case of the Bono Juancito Pinto, a part of the financial responsibility was then taken up by utility companies, some of them privatized, such as Boliviana de Aviacion, and some of them in public ownership, such as the public mining company COMIBOL. ${ }^{16}$

Table 8: Bolivia: sources of financing of the Renta Dignidad and Bono Juancito Pinto, 2006 to present (US\$ million; percentages given in parentheses)

(a) Renta Dignidad

\begin{tabular}{|c|c|c|c|c|c|c|c|c|c|c|}
\hline & 2006 & 2007 & 2008 & 2009 & 2010 & 2011 & 2012 & 2013 & 2014 & 2015 \\
\hline $\begin{array}{l}\text { Impuesto } \\
\text { Directo en los } \\
\text { Hidrocarburos } \\
\text { (IDH; direct tax } \\
\text { on gas and } \\
\text { petroleum) }\end{array}$ & & & $\begin{array}{l}190.0 \\
(100)\end{array}$ & $\begin{array}{c}235.0 \\
(63)\end{array}$ & $\begin{array}{c}250.1 \\
(68)\end{array}$ & $\begin{array}{c}296.3 \\
(77)\end{array}$ & $\begin{array}{c}436.4 \\
(84)\end{array}$ & $\begin{array}{c}568.9 \\
(77)\end{array}$ & $\begin{array}{c}593.5 \\
(68)\end{array}$ & $\begin{array}{c}527.6 \\
(81)\end{array}$ \\
\hline $\begin{array}{l}\text { Other } \\
\text { 'capitalized' } \\
\text { (privatized) } \\
\text { utilities }\end{array}$ & & & & $\begin{array}{c}131.1 \\
(35)\end{array}$ & $\begin{array}{c}114.5 \\
(30)\end{array}$ & $\begin{array}{l}81.2 \\
(21)\end{array}$ & $\begin{array}{l}73.1 \\
(14)\end{array}$ & $\begin{array}{c}164.3 \\
(22)\end{array}$ & $\begin{array}{c}276.8 \\
(31)\end{array}$ & $\begin{array}{c}122.8 \\
(19)\end{array}$ \\
\hline Other sources & & & & $\begin{array}{l}5.8 \\
(2)\end{array}$ & $\begin{array}{l}4.1 \\
(2)\end{array}$ & $\begin{array}{l}5.2 \\
(2)\end{array}$ & $\begin{array}{l}8.7 \\
(2)\end{array}$ & $\begin{array}{l}1.3 \\
(1)\end{array}$ & $\begin{array}{l}2.0 \\
(1)\end{array}$ & - \\
\hline Total & & & $\begin{array}{l}190.0 \\
(100)\end{array}$ & $\begin{array}{l}371.9 \\
(100)\end{array}$ & $\begin{array}{l}368.7 \\
(100)\end{array}$ & $\begin{array}{l}382.7 \\
(100)\end{array}$ & $\begin{array}{l}518.2 \\
(100)\end{array}$ & $\begin{array}{l}734.6 \\
(100)\end{array}$ & $\begin{array}{l}872.3 \\
(100)\end{array}$ & $\begin{array}{l}650.4 \\
(100)\end{array}$ \\
\hline
\end{tabular}

(b) Bono Juancito Pinto

\begin{tabular}{|c|c|c|c|c|c|c|c|c|c|}
\hline & 2006 & 2007 & 2008 & 2009 & 2010 & 2011 & 2012 & 2013 & 2014 \\
\hline \multicolumn{10}{|l|}{$I D H$} \\
\hline & $\begin{array}{c}41.3 \\
(100)\end{array}$ & $\begin{array}{l}26.2 \\
(33)\end{array}$ & & $\begin{array}{l}10.8 \\
(19)\end{array}$ & $\begin{array}{l}10.8 \\
(19)\end{array}$ & $\begin{array}{l}10.9 \\
(18)\end{array}$ & $\begin{array}{l}10.7 \\
(17)\end{array}$ & $\begin{array}{l}51.3 \\
(83)\end{array}$ & $\begin{array}{l}55.4 \\
(81)\end{array}$ \\
\hline National Treasury & & $\begin{array}{l}16.2 \\
(54)\end{array}$ & $\begin{array}{c}62.5 \\
(100)\end{array}$ & $\begin{array}{l}47.0 \\
(81)\end{array}$ & $\begin{array}{l}42.2 \\
(72)\end{array}$ & $\begin{array}{l}42.9 \\
(72)\end{array}$ & $\begin{array}{l}46.6 \\
(74)\end{array}$ & $\begin{array}{l}1.3 \\
(2)\end{array}$ & \\
\hline $\begin{array}{l}\text { COMIBOL } \\
\text { (Bolivian Mining } \\
\text { Corporation) }\end{array}$ & & $\begin{array}{c}6.6 \\
(13)\end{array}$ & & & $\begin{array}{l}5.4 \\
(9)\end{array}$ & $\begin{array}{l}5.4 \\
\text { (9) }\end{array}$ & $\begin{array}{l}4.6 \\
(7)\end{array}$ & $\begin{array}{l}4.4 \\
(7)\end{array}$ & $\begin{array}{l}4.2 \\
(6)\end{array}$ \\
\hline $\begin{array}{l}\text { ENTEL } \\
\text { (Bolivian } \\
\text { Telecommunication } \\
\text { s Corporation) }\end{array}$ & & & & & & & & $\begin{array}{l}1.1 \\
(2)\end{array}$ & $\begin{array}{l}4.2 \\
(6)\end{array}$ \\
\hline Other 'capitalized' & & & & & & & & 3.3 & 4.5 \\
\hline
\end{tabular}

16 The third 'linked' bond, the Bono Juana Azurduy, is and has always been 100 per cent financed by the National Treasury, although there is currently discussion of transferring some of its financing, also, to Bolivia's utility companies (interview, Cecilia Vidal Fuertes, UDAPE, 30 July 2015). 


\begin{tabular}{lccccccccc}
\hline (privatized) utilities & & & & & & & & $(6)$ & $(7)$ \\
Total & 41.3 & 49.0 & 62.5 & 57.8 & 58.6 & 59.2 & 63.0 & 64.3 & 68.3 \\
& $(100)$ & $(100)$ & $(100)$ & $(100)$ & $(100)$ & $(100)$ & $(100)$ & $(100)$ & $(100)$ \\
\hline
\end{tabular}

Source: UDAPE, personal communication.

Thus, as the vulnerable downside of linked taxation in the shape of falling mineral prices has been exposed, so governments wishing to finance social protection in this way have been forced to diversify their sources of revenue.

\section{Conclusions}

In this paper we have portrayed the emergence of transformative, pro-poor fiscal policy as a two-stage process. In the first stage, some developing-country governments have taken advantage of democratization and a loosening of pressures from international agencies to raise rates of taxation on minerals and other exports generated principally by multinational corporations - and in some cases user charges and VAT - thereby enabling very poor countries to exit from the low-tax, low-expenditure trap, broadening the basis of public expenditure, and helping to subvert 'Director's Law'. The second stage is to build on this to create a competitive and diversified export sector.

In this paper, which concentrates on Africa and Latin America, we have shown that both progressive taxation and the expansion of social protection-and, in five countries, the making of a linkage between the two by means of earmarked natural-resource taxation-has enabled governments to make a plausible approach to groups of 'floating' or 'swing' voters who are not committed on grounds of ethnic, regional, or ideological loyalty to any of the main political parties - and gain their support by promising an expansion of expenditures focused on them, and a decrease in the rates of unpopular taxes. In the process, the tax base has been strengthened and broadened, making possible an expansion of public expenditure and investment. The expansion of social protection has not only won political support, but in both Bolivia and Ghana has significantly reduced headcount poverty, and across all five countries also appears —although the data are controversial - to have reduced the government's chronic political instability. There are also resource costs associated with linked taxation, but in the final section we have examined how governments have reduced those costs by shifting from royalty-based towards incomebased taxation and by broadening the range of sources from which linked taxation is derived.

\section{References}

Abdulai, A.-G. (2016). 'Rethinking the Politics of Mining and Development in Ghana? A Political Settlements Approach'. ESID working paper. Manchester: University of Manchester.

Adam, C., and S. O'Connell (2006). 'Monetary Policy and Aid Management in Sub-Saharan Africa'. Unpublished paper, University of Oxford and Swarthmore College.

Addison, T., M. Niño-Zarazua, and J.M. Vila (2016). 'Natural Resources, Electoral Behaviour and Social Assistance in Latin America'. Unpublished paper, UNU-WIDER.

Ali, M., O.-H. Fjeldstad, and I.H. Sjursen (2014). 'To Pay or Not to Pay?' Citizens' Attitudes Towards Taxation in Kenya, Uganda, and South Africa', World Development, 64: 828-42. 
Altamar, P. (2006). Evaluación de impacto del Proyecto Atención para el Bienestar del Adulto Mayor en Pobreza en Bogotá D.C. 2004-2006 [Impact Evaluation of the Project on Support for Older People in Bogotá D.C. 2004-2006]. Mexico City: Facultad Latinoamericana de Ciencias Sociales.

Arauco, V.P. (2014). Nuevos caminos de la politica social en Bolivia: el rol de las transferencias en efectivo 2006-2012 [New directions for social policy in Bolivia: the role of cash transfers 20062012]. Vice-Presidency of Bolivia/UNDP.

Barrientos, A. (2005). 'Non-Contributory Pensions and Poverty Reduction Policies of the United Kingdom Government'. Report for DFID by IDPM, University of Manchester.

Barrientos, A. (2013). Social Assistance in Developing Countries. Cambridge: Cambridge University Press.

Barrientos, A., and C. Santibañez (2009). 'New Forms of Social Assistance and the Evolution of Social Protection in Latin America'. Journal of Latin American Studies, 41: 1-26.

Bastagli, F. (2015). 'Bringing Taxation into Social Protection Analysis and Planning'. Working paper 421. London: ODI.

Bergman, M. (2003). 'Tax Reforms and Tax Compliance: The Divergent Paths of Chile and Argentina'. Journal of Latin American Studies, 35: 593-624.

Bodea, C., and A. Le Bas (2013). 'The Origins of Social Contracts: Attitudes Towards Taxation in Urban Nigeria'. Working paper 2013-02. Oxford: Centre for the Study of African Economies.

Brautigam, D., O. Fjeldstad, and M. Moore (2008). Taxation and State-Building in Developing Countries: Capacity and Consent. Cambridge: Cambridge University Press.

Bravo-Escobar, E. (2007). 'Straddling the State and Civil Society: Social Organisation, Social Capital and Development Strategies in Venezuela'. Paper presented at the 27th International Congress of the Latin American Studies Association, Montreal.

Bulmer-Thomas, V. (2014), The Economic History of Latin America Since Independence. Cambridge: Cambridge University Press.

Buxton, J. (2009). 'The Bolivarian Revolution as Venezuela's Post-Crisis Alternative'. In J. Grugel and P. Riggirozzi (eds), Governance After Neoliberalism in Latin America. Basingstoke: Palgrave Macmillan.

Canales, C., and M. Niño-Zarazua (2016). 'Schooling and Labour Market Impacts of Bolivia's "Bono Juancito Pinto"”. Unpublished paper, UNU/WIDER.

Cardoso, E., and A. Helwege (1995). Latin America's Economy: Diversity, Trends and Conflicts. Cambridge, MA: MIT Press.

Cheeseman, N., and M. Hinfelaar (2010). 'Parties, Platforms and Political Mobilisation: The Zambian Presidential Election of 2008'. African Affairs, 109: 51-76.

Christian Aid, in association with Action Aid, Southern Africa Resource Watch, and Tax Justice Network for Africa (2009). Breaking the Curse: How Transparent Taxation and Fair Taxes Can Turn Africa's Mineral Wealth into Development. London: Christian Aid.

Eaton, K. (2013). 'The Centralism of "Twenty-first Century Socialism": Recentralising Politics in Venezuela, Ecuador and Bolivia'. Journal of Latin American Studies, 45: 421-50.

Escobar Loza, F. Martínez, S. Wilde, and J. Mendizábal Córdova (2013). Evaluación de Impacto de la Renta Dignidad y resultados de la encuesta EPAM-2011 [Impact Evaluation of the Renta Dignidad and Results of the EPAM-2011 Inquiry]. La Paz: UDAPE. 
Fraser, A., and M. Larmer (2010). Zambia, Mining and Neoliberalism. Basingstoke: Palgrave Macmillan.

Fuertes, C.V., S. Martínez, P. Celhay, and S.C. Gómez (2015). Evaluación de Impacto 'Bono Juana Azurduy [Impact Evaluation of the Bono Juana Azurduy]. La Paz: UDAPE/Inter-American Development Bank.

García-Guadilla, M. (2007). 'El Poder Popular y la Democracia Participativa en Venezuela: Los Consejos Comunales'. Paper presented at the 27th International Congress of the Latin American Studies Association, Montreal.

Gemmell, N., and O. Morrissey (2003). 'Tax Structure and the Incidence on the Poor in Developing Countries'. CREDIT research paper 03/18. Nottingham: Centre for Research on Economic Development and International Trade.

Gemmell, N., and O. Morrissey (2005). 'Distribution and Poverty Impacts of Tax Structure Reform in Developing Countries: How Little We Know'. Development Policy Review, 23: 13144.

Ghanaian Government (2014). Ghana Living Standards Survey 2014. Accra: Government Printer.

Gomez Sabaini, J.C, J.P. Jiménez, and D. Morán (2015). El impacto fiscal de la explotación de los recursos naturales no renovables en los países de América Latina y el Caribe [The Fiscal Impact of Non-renewable Resource Development in Latin America and the Caribbean]. Working paper LC/W.658. Santiago: CEPAL.

Grugel, J., and P. Riggirozzi (eds) (2009). Governance After Neoliberalism in Latin America. Basingstoke: Palgrave Macmillan.

International Monetary Fund (IMF) (2014). 'Ghana-Article IV Consultation-Staff Report; Press Release; and Statement by the Executive Director for Ghana'. IMF Country Report 14/129. Washington DC: IMF.

Jehu-Appiah, C., G. Aryeetey, E. Spaan, T. de Hoop, I. Agyepong, and R. Baltussen (2011). 'Equity Aspects of the National Health Insurance Scheme in Ghana: Who is Enrolling, Who is Not and Why?' Social Science and Medicine, 72: 157-65.

Laserna, R. (2011). La Trampa del Rentismo...y Como Salir de Ella [The Rent-seeking Trap, and How to Escape From it]. La Paz: CERES.

Lustig, N., C. Pessino, and S. Higgins (2013). 'The Impact of Taxes and Social Spending on Inequality and Poverty in Argentina, Bolivia, Brazil, Mexico, Peru and Uruguay'. Commitment to Equity assessment working paper 13. Tulane, NO: Commitment to Equity.

Martínez, S., F. Escobar, and J. Mendizabal (2014). 'Impact of Bolivia's Universal Pension on Income, Consumption and Poverty'. Unpublished paper.

Mofya-Mukuka, R., S. Kabwe, A. Kuteya, and N. Mason (2013). 'How Can the Zambian Government Improve the Targeting of the Farmer Input Supply Programme?' Policy Brief 59. Lusaka: Indaba Agricultural Policy Institute.

Montúfar, C. (2009). 'Revolución de izquierda en América Latina? Un mito, y además... mediático' [A Left-wing Revolution in Latin America? A Myth, Put Out by the Media]. Nueva Crónica, 20 February.

Moore, M. (1999), 'Death Without Taxes: Democracy, State Capacity and Aid Dependence in the Fourth World'. In G. White and M. Robinson (eds), Towards a Democratic Developmental State. Oxford: Oxford University Press.

Mosley, P. (2012). The Politics of Poverty Reduction. Oxford: Oxford University Press. 
Mosley, P. (2014a). 'Progressive Export Taxation as a Solution to the "Natural Resource Curse" Problem: Zambia Case Study'. Unpublished paper, University of Manchester.

Mosley, P. (2014b). 'Progressive Export Taxation as a Solution to the "Natural Resource Curse" Problem: Bolivia Case Study'. Unpublished paper, University of Manchester.

Mosley, P. (2015a). 'Fiscal Composition and Aid-Effectiveness: A Political Economy Model'. World Development, 69: 106-15.

Mosley, P. (2015b) 'The Fiscal Politics of Mineral Development in Ghana'. Unpublished paper.

Mosley, P. (2017). Fiscal Policy and the Natural Resource Curse: How to Escape from the Poverty Trap. London: Routledge.

Mosley, P., A. Abdul-Gafaru, and B. Chiripanhura (2015). 'The Politics of Progressive Fiscal Policy: A Study of Resource-Intensive Regimes in Africa'. Unpublished paper.

Oporto, H., D. Garzón, J. Espinosa, and P. Portugal (2012). Los dilemas de la minería [Dilemmas of the Bolivian mining industry]. La Paz: Fundación Vicente Panos Kanki.

Oxford Policy Management (2014). Macro-Economic Impacts of Mining in Zambia. Report. International Commission on Mining and Metals.

Prichard, W. (2009). 'The Politics of Taxation and Implications for Accountability in Ghana 1981-2008'. Working Paper 330. Brighton: Institute of Development Studies.

Puentes, G. (2009). 'Unravelling the Policy-Making Process: The Case of Chilean PovertyAlleviation Policy'. PhD thesis, London School of Economics.

Scholz, J., and M. Lubell (1998). 'Trust and Taxpaying: Testing the Heuristic Approach to Collective Action'. American Journal of Political Science, 42: 398-417.

Stigler, G. (1970). 'Director's Law of Public Income Redistribution'. Journal of Law and Economics, 13: $1-10$.

UDAPE (Unidad de Analisis de Politicas Economicas y Sociales) (2013). Septimo informe de progreso de los objetivos de desarollo del Milenio en Bolivia (Bolivia, Seventh Millennium Development Goals Progress Report). La Paz: UDAPE.

Wodon, Q. (ed.) (2012). Improving the Targeting of Social Programmes in Ghana. Washington, DC: World Bank.

World Bank (2011). Tackling Poverty in Northern Ghana. Washington, DC: World Bank.

Zambian Government (2013). 2014 Budget Address by the Minister of Finance, Alexander Chikwanda MP. Lusaka: Government Printer. 